Board of Governors of the Federal Reserve System

International Finance Discussion Papers

Number 689

December 2000

\title{
SIZE, CHARTER VALUE AND RISK IN BANKING: AN INTERNATIONAL PERSPECTIVE
}

\author{
Gianni De Nicoló
}

NOTE: International Finance Discussion Papers are preliminary materials circulated to stimulate discussion and critical comment. References in publications to International Finance Discussion Papers (other than an acknowledgement that the writer has had access to unpublished material) should be cleared with the author or authors. Recent IFDPs are available on the Web at www.bog.frb.fed.us. 


\title{
SIZE, CHARTER VALUE AND RISK IN BANKING: AN INTERNATIONAL PERSPECTIVE
}

\author{
Gianni De Nicoló *
}

\begin{abstract}
This paper documents the relationships between bank size and measures of charter value and insolvency risk in a sample of publicly traded banks in 21 industrialized countries for the 1988-1998 period. With the exception of small U.S. bank holding companies, charter values decrease in size and insolvency risk increases in size for most banks in the countries considered. Size-related diversification benefits and/or economies of scale in intermediation are either absent or, if they exist, are more than offset by banks' higher risk taking. Furthermore, banks operating in countries with more developed financial markets exhibit lower insolvency risk, and those operating in countries with either stricter regulation on banks' permissible activities or larger share of bank assets under state ownership exhibit higher insolvency risk. Overall, our evidence is at variance with some broad implications of modern financial intermediation theory, and suggests that absent future structural changes in banking markets of developed countries, bank consolidation is likely to result in an average increase in banks' insolvency risk.
\end{abstract}

Keywords: Bank Risk, Charter Value, Size, Consolidation.

JEL Classifications: G2, L8.

* The author is staff economist in the Division of International Finance, Board of Governors of the Federal Reserve System. He would like to thank John Boyd, Fabio Canova, participants in seminars held at the Federal Reserve Board, FED Richmond, the IMF, and participants in the IX Tor Vergata Financial Conference, for useful comments and suggestions. The views in this paper are solely the responsibility of the author and should not be interpreted as reflecting the views of the Board of Governors of the Federal Reserve System or of any other person associated with the Federal Reserve System 


\section{Introduction and Summary}

Mergers and acquisitions activity in banking has been intense in most industrialized countries in the last decade, and has substantially accelerated in the past few years. A clear outcome of the bank mergers' wave is a sharp increase in the average size of banking organizations. Is the riskadjusted performance of larger banks superior to that of smaller banks? Is their insolvency risk lower? Answers to these questions are important to understand both bank mergers' main drivers as well as the public policy implications of bank consolidation. A more general and important question pertains to the ability of existing banking theories to rationalize key aspects of the crosssectional relationship between size, charter value and risk. This paper empirically addresses these questions in an international perspective. The cross-sectional relationships between bank size and market measures of charter value and insolvency risk is documented for a sample of publicly traded banks in 21 industrialized countries for the 1988-1998 period. The evidence is discussed in light of some broad implications of theory, and with respect to the potential implications of bank consolidation on banks' insolvency risk.

Few studies focus on the cross-sectional relationships between bank size, charter value and risk in the U.S. using market data. To the best of our knowledge, no paper documents such relationships for banks in other countries. The study by Boyd and Runkle (1993) (hereafter BR) is unique in confronting explicitly some broad implications of modern intermediation theory with the data: this paper builds on their effort, and can be viewed as a substantial update and extension of their study.

The relationships between bank size, charter value and risk are documented by means of simple cross-sectional regressions specified consistently with a broad notion of banking industry equilibrium. As in BR, charter value is measured by an estimate of banks' Tobin's q, and insolvency risk by a Z-score type measure. Regressions are estimated for samples of banks in eight countries taken individually, for a pool of banks in the 17 European countries in the sample, and for the entire pool of banks in the 21 countries considered. In our pooled regressions, we introduce level effects associated with some structural variables called environmental. These variables index country-specific institutional and regulatory features of the environment in which banks operate, and turn out to track relevant portions of cross-country variations in average measures of charter value and insolvency risk. The assessment of their impact on banks' charter

value and insolvency risk in industrialized countries is a novel and important contribution of this paper. 
Our investigation yields two sets of results.

The first set regards the cross-sectional relationships between charter value, insolvency risk and size for banks in each country. First, medium-to-large banks in the U.S., Japan, and in three out of the six European countries considered exhibit charter values that decrease in size. Second, for medium-to-large banks in the U.S., Japan and the six European countries considered individually, insolvency risk increases in size. The positive relationship between size and insolvency risk is also found for the European pooled sample as well as for the complete pooled sample of all banks in the 21 countries considered. Third, banks' returns on assets and market capital-to-asset ratios decrease in size, and bank returns' volatility increases in size. In other words, larger banks' sizes are mapped into lower return-higher risk points on a hypothetical risk-return frontier, as well as into lower volatility-adjusted capital ratios. All these results hold for estimates of the cross sectional relationships for the period 1988-1998, as well as for the sub-periods 1988-1993 and 1994-1998.

These findings indicate that size-related diversification benefits and/or economies of scale in bank intermediation are either absent or, if they exist, are more than offset by banks' higher risk taking. Noticeably, we find that charter value is increasing in size and insolvency risk is decreasing in size for small U.S. bank holding companies. An interpretation of this finding is that small U.S. BHCs exhibit economically relevant economies of scale, that is economies that are reflected in banks' market valuation, and are exhausted at a relatively small size range.

The second set of results regards the impact of the environmental variables on charter value and insolvency risk. First, banks operating in countries with more developed financial markets exhibit higher charter values and lower insolvency risk. This result is consistent with the existence of a positive externality between financial markets development and banks' (risk-adjusted) performance. Second, banks operating in countries with stricter regulatory restrictions on banks' permissible activities exhibit higher insolvency risk. This result is consistent with the existence of diversification opportunities associated with universal banking. Third, banks operating in countries with a larger banks' state ownership exhibit higher insolvency risk. Since our samples include very few banks with a state majority interest, this finding is evidence of direct as well as indirect effects of state ownership on bank behavior. Indirect effects may include the creation of incentives for private banks to take on more risk in response to subsidized state banks' competition.

We draw two main conclusions from our investigation. First, some of the broad implications of theory, such as a predicted positive relationship between size and charter value, and a negative 
relationship between size and insolvency risk, are rejected by the data, just as they were in BR. Thus, our study supports the development of theories which emphasize the study of incentives for banking firms in exploiting sources of comparative advantages, such as diversification benefits, under different regulatory and safety net structures, and the continued modelling of imperfect competion in banking. Second, the finding of a positive relationship between insolvency risk and size, and the absence of a positive relationship between charter values and size in most banking systems of developed countries is consistent with the lack of robust evidence regarding the efficiency gains associated with large banks' mergers. This fact suggests that in the absence of future structural changes in the fundamentals of technologies and incentive structures of banking markets in developed countries, bank consolidation is likely to result in an average increase in banks' insolvency risk.

The paper is structured as follows. In the next section some implications of theory regarding the cross sectional relationships between bank size, charter value and risk are outlined. This theoretical background provides the basis of our empirical analysis. Section 3 describes variables measurements, statistics and data considered. Section 4 presents the results, and section 5 discusses them in light of the implications of theory and in terms of the potential implications of bank consolidation for banks' insolvency risk.

\section{Theory}

A first strand of theory views a bank as a managed portfolio of risky claims, and assesses the incentives on risk taking under fixed rate deposit insurance. The partial equilibrium version of this theory, pioneered by Merton (1977) and Kareken and Wallace(1978), asserts that absent regulation limiting risk taking, a bank manager acting in shareholders' interests will make investment decisions so as to attain the maximum feasible risk profile. ${ }^{1}$ The theory provides a rationale for regulations controlling risks, such as risk-based capital requirements and riskadjusted deposit insurance premiums, in order to limit the liability of the institutions backing the safety net. The importance of ex-ante incentive compatible closure and/or liquidation rules as necessary tools to limit the amount of banks' risk taking is stressed by a portion of the literature (see e.g. Freixas and Rochet $(1997$, ch.7)). Tough rules, such as management replacement

\footnotetext{
${ }^{1}$ Managers' objectives can be aligned to shareholders' through compensation schemes sensitive to banks' market performance. Interestingly, Demsetz and Saidenberg (1999) document that differences in executive compensation among U.S. banks are primarily due to bank's size. Executives at large banks, and particularly CEOs, receive a greater share of compensation in the form of annual bonuses and option-adjusted compensation than at smaller banks.
} 
and shareholders bearing the full cost of a bank failure, may improve ex-ante control of bank risk-taking, although in some models even ex-ante tough rules might be inefficient or encounter credibility problems (see Mailath and Mester (1994), Aghion et al. (1999)).

Yet, the liquidity and/or solvency problems of large banking institutions are precisely those whose negative externalities are perceived as threatening financial stability. The outright failure and liquidation of a large bank is usually viewed as associated with large social costs. The uncertainty regarding possible systemic risk consequences of outright failures of large banks, and the resolution difficulties that can arise from their liquidation, may create differential incentives for risk-taking in large banks. For example, if managers of failed or problem banks are difficult to replace, bank managers might enjoy a renegotiation (entrenchment) option, whose value is likely to increase in size. Partly for this reason, it is likely that tough ex-ante bank closure rules might apply more credibly and efficiently to smaller than larger banks, i.e. institutions whose failure is devoid of systemic risk implications. Borrowing a term introduced by Kane (2000), large banks may be too-big-to-discipline adequately (TBTDA) and, as a consequence, may enjoy a safety-net subsidy higher than smaller banks.

However, regulators can impose more stringent regulations on large banks. Thus, if firms have access to the same investment opportunity set, in an equilibrium in which for all firms regulatory constraints on risk taking are binding, as predicted by theory, then banks' insolvency risk should decrease in size for sizes greater than that threshold level perceived by regulators as one above which systemic risk considerations are relevant. More stringent size-related regulations may also reduce the subsidy component of deposit insurance.

Since the net effect of higher subsidies due to TBTDA and differential regulation for large banks on bank risk taking is uncertain without further assumptions, theory delivers the following:

Prediction 1 Either bank insolvency risk is decreasing in size, or the safety net subsidy is increasing in size, or both, for all sizes greater than a certain size threshold.

The basic theory has been extended in several directions. The incentives for lower banks' risk taking induced by the threat of loss of charter value, first pointed out by Marcus(1984), have been recently analized in the context of optimal regulation by Marshall and Prescott (2000) and Acharya (2000). The interplay between risk taking, charter value, competition and deposit insurance has been analyzed by Helmann, Murdock and Stiglitz (2000), Allen and Gale (2000) and Matutes and Vives (2000). An implication common to these models is that, ceteris paribus, a more competitive banking system should be also one in which banks take on more risk: the 
reason is that monopoly rents, by pushing up charter values, would deter banks' higher risk taking, since banks would have a higher charter value to loose in case of failure. ${ }^{2}$ Yet, none of these models yields implications regarding the relationship between size and charter value, and size and insolvency risk. ${ }^{3}$. The only exception is the model by Buchinsky and Yosha (1997), where the probability of failure of intermediaries and their size distribution are jointly and endogenously determined in a dynamic industry equilibrium. However, there is no deposit insurance in their model. In sum, we treat prediction 1 as a useful benchmark, and use the insights of recent developments of the literature as an aid to the interpretation of the evidence.

A second strand of theory identifies economies of scale and scope in information production as a rationale for the special role of financial intermediaries. Earlier models predict informational economies of scale for intermediation activities due to the savings in screening and monitoring costs allowed by diversification (see e.g. Diamond (1984), Williamson (1986) and Boyd and Prescott (1986)). A direct implication of these theories is that larger banks should be less likely to fail and more efficient than smaller banks. Put it differently, larger banks should choose a higher point on a hypothetical risk-return frontier due to enhanced diversification opportunities and economies of scale in information production, monitoring and transaction costs.

Recent developments of this theory, however, stress the existence of more complex relationships between informational economies of scale, diversification opportunities and risk. Krasa and Villamil (1992) identify informational dis-economies of scale due to a replication of information production costs. In choosing an optimal portfolio size, a bank will trade-off the decrease in default probability attained through a larger and more diversified portfolio with increases in the monitoring costs of the bank incurred by lenders. Thus, the equilibrium bank size distribution depends on the structure of monitoring costs, and under specific assumptions about the monitoring technology, there may exist a threshold size over which the costs incurred by lenders to monitor the intermediary outweigh the savings of monitoring costs that an intermediary achieves through size-related diversification.

Importantly, two contributions identify a potential trade-off between diversification and spe-

\footnotetext{
${ }^{2}$ Keeley(1990) and Demsetz, Sadenberg and Strahan (1996) provide empirical evidence for U.S. banks, and Gopp and Vesala (2000) for a sample of European banks.

${ }^{3}$ It is important to stress that the development of these models is still at an early stage, in part because of their partial equilibrium set-ups, and partly because of their exogenous assumption of the type of contract written between an intermediary and its counterparties. Recently, Boyd, Chang and Smith (2000) analyze banks' risk taking incentives under different deposit insurance arrangements in a general equilibrium framework where contracts are derived, and show that some implications of partial equilibrium set-ups with exogenous contracts may be overturned.
} 
cialization that may imply that diversification opportunities, although available by increases in size, do not necessarily lead to a lower insolvency risk. Hellwig(1998) analyzes this trade-off in the context of an extension of Diamond's delegated monitoring technology. An intermediary is allowed to choose both the number and size of projects to be financed. It specializes by funding a small number of projects on a large scale, or it diversifies by investing small amounts of resources in a large number of projects. Under fixed monitoring costs and constant returns to scale technologies, Hellwig shows that the intermediary takes on the maximum feasible amount of risk. Winton (1999) characterizes the circumstances under which specialization may dominate diversification. He shows that the ranking of these bank strategies in terms of risk of failure may be non-monotonic: diversification (specialization) may actually increase (decrease) the probability of insolvency. The occurrence of such outcomes would depend on the structure of monitoring costs and the skewness of loan return distributions.

Indipendently of the different assumptions on which these models are built, they all stress an important point: if economies of scale and the benefits of diversification associated with larger sizes are of any economic significance, then this fact should be incorporated in banks' market valuation. Hence, we view as a broad implication of this theory the following:

Prediction 2 If economies of scale and/or diversification benefits associated with large sizes are economically relevant, then banks' charter value should increase in size and insolvency risk should decrease in size for some size range.

To illustrate the relationships between bank's size, charter value and risk in an industry equilibrium, it is convenient to introduce some notation. Let $A$ denote assets, $E$ denote equity, $K=\frac{E}{A}$ denote the equity-to-asset ratio, $\pi$ denote shareholders' profits, $r=\pi / A$ denote returns on assets, and let a bank's return distribution be denoted by $F(r)$, with first and second moments denoted by $\mu$ and $\sigma^{2}$ respectively.

Tobin's $q$, defined as the ratio of the market value of a bank over its replacement cost, is an appropriate measure of charter value, since $q$ includes the discounted value of (i) rents due to competitive advantage arising from differential managerial skills, (ii) rents due to market power and (iii) rents accruing from any safety net subsidy (see e.g. Lindenberg and Ross (1981)). Since market investors have preferences over return and risk, $q$ can be also viewed as a size-scaled, risk-weighted measure of bank performance gross of rents accruing from market power and safety net subsidies.

Insolvency risk is defined as the probability that losses (negative profits) exceed equity, i.e.: 


$$
P(\pi \leq-E)=P(r \leq-K)=\int_{-\infty}^{-K} F(r) d r
$$

As shown by Roy (1952), if $\mu$ and $\sigma^{2}$ exist then Chebishev inequality implies that

$$
P(r \leq-K) \leq \frac{\sigma^{2}}{(\mu+K)^{2}}=\frac{1}{z^{2}}
$$

where

$$
z \equiv \frac{\mu+\frac{E}{A}}{\sigma}
$$

Hence, a higher level of $z$ corresponds to a lower upper bound of insolvency risk.

Under the assumption of normality of banks' returns, $z$ is an estimate of a bank's probability of failure, since

$$
P(r \leq-K)=\int_{-\infty}^{-z} N(0,1) d r
$$

In this case, $z$ measures the number of standard deviations a return realization has to fall in order to deplete equity. We take $z$ as our measure of insolvency risk.

In equilibrium, an equilibrium distribution of $q_{i}$ and $z_{i}$ is induced by distributions of $F_{i}(R)$ and $K_{i}$, where subsript $i$ denotes a bank. In turn, these distributions are functions of a given size distribution, and other factors which we refer to as environmental, and denote by $E$. Thus, an equilibrium can be viewed as schematically represented by:

$$
\begin{aligned}
& q\left(F_{i}(R), K_{i}\right)=q\left(T_{1}\left(A_{i}\right), S_{1}\left(A_{i}\right), M_{p}^{1}\left(A_{i}\right), E\right) \\
& z\left(F_{i}(R), K_{i}\right)=z\left(T_{2}\left(A_{i}\right), S_{2}\left(A_{i}\right), M_{p}^{2}\left(A_{i}\right), E\right)
\end{aligned}
$$

where functions $T(A)$ denotes technology, $S(A)$ denotes safety net subsidy and $M_{p}(A)$ denotes market power. Theory restricts the form of these functions. Prediction 1 implies that either function $S_{1}(A)$ is increasing or function $T_{2}(A)$ is decreasing, or both, for all sizes grater than a certain size threshold. Prediction 2 implies that function $T_{1}(A)$ is increasing and $T_{2}(A)$ is decreasing in size.

In our empirical analysis we do not control for market power because of the lack of a satisfactory proxy of market power that could be constructed on the basis of information in our database. For this reason, we will discuss our empirical results by asking which assumptions on functions $M_{p}^{1}(A)$ and $M_{p}^{2}(A)$, if any, are necessary to reconcile the predictions of theory with the evidence. 


\section{Empirics}

\subsection{Measurement}

Bank $i$ 's charter value is proxied by the market-to-book asset ratio:

$$
Q_{i}(t)=\frac{E_{M}^{i}(t)+L_{B}^{i}(t)}{A_{B}^{i}(t)}
$$

where $E_{M}^{i}(t)$ is the market value of equity, $L_{B}^{i}(t)$ is the accounting value of liabilities, $A_{B}^{i}(t)$ is the accounting value of assets, and all measures are taken at the end of year $t$. Thus, the market value of assets is proxied by the sum of the market value of equity plus the accounting value of liabilities, i.e. $A_{M}^{i}(t) \equiv E_{M}^{i}(t)+L_{B}^{i}(t)$. The replacement cost of assets is proxied by accounting assets. As discussed in BR, measurement errors may be present in both the numerator and the denominator. Accounting liabilities may be a good proxy of the market value of liabilities at each point in time if most liabilities are short term. This is approximately true in banking, where a large fraction of liabilities are demand deposits. However, banks' increased reliance on market sources of funding makes the market value of liabilities more sensitive to changes in interest rates that are not recorded by accounting measures of liabilities at each point in time. Measurement errors may be also present in the denominator at each point in time, since capital gains and losses may be deferred in time. However, both these sources of measurement errors are substantially reduced when averages of the market-to-book asset ratio are computed over a relatively long time period, since accounting and market values of liabilities are likely to converge and capital gains and losses cannot be deferred indefinetely. In our case, measurement errors do not appear to distort in any relevant way our estimates of regression (3), since all results presented below are unchanged when we use as a proxy of charter value the market-to-book equity ratio, which is not affected by measurement errors.

Total shareholders' profits in bank's $i$ are measured by

$$
\Pi_{i}(t)=N_{i}(t) \frac{P_{i}(t)-P_{i}(t-1)+D_{i}(t)}{P_{i}(t-1)}
$$

where $N_{i}(t)$ is the number of shares outstanding, $P_{i}(t)$ is the price of shares, and $D_{i}(t)$ is dividends at the end of date $t$. Thus, bank's $i$ returns on assets are measured by $R_{i}(t)=$ $\Pi_{i}(t) / A_{M}(t)$. Return volatility is measured by the annualized monthly standard deviation of bank's $i$ returns on assets in year $t$.

Insolvency risk for bank's $i$ is measured by:

$$
Z_{i}=\frac{\hat{\mu}_{i}+\left(\frac{E}{A}\right)_{i}}{\hat{\sigma}_{i}}
$$


where $\hat{\mu}_{i}$ and $\hat{\sigma}_{i}$ are sample estimates of the mean and standard deviation of bank's $i$ returns on assets, and $(E / A)_{i}$ is the time average of the market capital-to-asset ratio.

Finally, bank size is measured by the accounting value of total assets. All our results are unchanged with the alternative use of the proxy of the market value of assets $A_{M}^{i}(t)$ as a measure of bank size.

\subsection{Statistics}

The relationships between risk, charter value and size are documented by estimates of the coefficients of the following set of cross-sectional regressions:

$$
\begin{gathered}
Q_{i}=\alpha_{0}+\alpha_{1} A_{i}+\alpha_{2} G\left(A_{i}\right)+\epsilon_{i}^{1} \\
Z_{i}=\beta_{0}+\beta_{1} A_{i}+\beta_{2} G\left(A_{i}\right)+\epsilon_{i}^{2} \\
R_{i}=a_{0}+a_{1} A_{i}+a_{2} G\left(A_{i}\right)+\epsilon_{i}^{3} \\
\left(\frac{E}{A}\right)_{i}=b_{0}+b_{1} A_{i}+b_{2} G\left(A_{i}\right)+\epsilon_{i}^{4} \\
\sigma_{i}=c_{0}+c_{1} A_{i}+c_{2} G\left(A_{i}\right)+\epsilon_{i}^{5}
\end{gathered}
$$

With the exception of the average annualized continuosly compounded growth rate of assets of bank's $i$, denoted by $G\left(A_{i}\right)$, all other variables are log-transformed time averages. That is, $X_{i} \equiv \log \left(T^{-1} \sum_{t} X_{i t}\right)$, where $X_{i t}$ is bank's $i$ measure of assets, charter value, insolvency risk and its components in each year $t$, and $T$ is the lenght of the time period in years. Size growth is included to control for firms' differences in growth rates, which are likely to be relevant especially in a consolidating industry. Notice that if a bank is assumed to grow permanently at a constant rate, then the sum of the size and the size growth coefficients measures the net effect of a permament increase of bank size on charter value, insolvency risk and its components.

The specification adopted is consistent with a notion of (long-run) industry equilibrium suggested by theory. In fact, equations (3) and (4) can be viewed as a linearized version of the stylized equilibrium relationships (1) and (2). Thus, prediction 1 implies that either $\alpha_{1}>0$, or $\beta_{1}>0$, or $\alpha_{1}>0$ and $\beta_{1}>0$. Prediction 2 implies that $\alpha_{1}$ and $\beta_{1}>0$ should hold. Equations (5)-(7) provide information regarding the relationship between size and the components of $Z$. 
The cross-sectional relationships between size and the ratio of returns on assets over volatility, which proxies a point on a hypothetical risk-return frontier, is measured by the difference between the size coefficients of equations (5) and (7). The cross-sectional relationships between size and the market capital-to-asset ratio relative to volatility, which may be viewed as a proxy measure of a risk-adjusted capital ratio, is measured by the difference between the size coefficients of equations (6) and (7).

The log-linear specification partially accounts for possible non-linearities. Yet, non-linearities might be important in our case. Subject to the constraints of data availability, piecewise regressions were estimated on asset classes, as detailed below.

\subsection{Data}

The data employed in this study are taken from the Wordscope database. We collected consolidated accounting and market data for a panel of publicly traded banks in 21 countries (Australia, Canada, Japan, Norway, Switzerland, the U.S. and the 15 European Union countries) for the 1988-1998 period. Coverage of the database is extensive, since virtually all publicly traded banks are included in each country sample.

The panel data set is unbalanced due to mergers and acquisitions. As typical in databases of this kind, Worldscope delists banks acquired by other banks with a lag of two years from the acquisition date. To eliminate the survivorship bias induced by the use of the sample of firms present in the database at the most recent reporting date, we re-inserted all targets of mergers and acquisitions using older database's CD-ROMs.

Banks with less than 3 years of data for the 1988-1998 period, and with missing values in at least one variable of interest, were discarded from the sample. This selection criteria produced a final sample containing data on 826 banks for the 21 countries considered, including 419 U.S. BHCs, 118 Japanese banks and 271 European banks. It is worth mentioning, however, that our results are qualitatively unchanged when we include all banks in the database.

The size of a bank for the 1988-1998 period is measured by the average of the accounting value of assets, converted in US\$ at the 1998-1998 average exchange rate. Table 1 reports statistics on the size distribution of banks for each country, for the European pooled sample, and the entire pooled sample. It is apparent that there is a large variation of sizes in all country samples with a relatively large number of observations. 


\section{Results}

Regressions (3)-(7) were estimated separately for banks in the U.S., Japan and six European countries for the entire 1988-1998 period, and for two time sub-periods, 1998-1993 and 1994-1995.

The U.S. and Japanese sample contain enough observations to estimate piecewise regressions for four asset classes. Asset classes were simply selected to satisfy the requirement that the number of each observation is approximately the same in each class. Each asset class is defined as observations falling in each quartile of the size distributions. The four asset classes corresponding to the first, second, third and fourth quartiles are denoted with Q1, Q2, Q3 and Q4 respectively. Table 1 provides size bounds of each asset class.

We report results for those European countries (Denmark, France, Germany, Italy, Spain and Switzerland) in which the number of banks is greater than twenty. Despite the potential imprecision of the estimates due to the small number of observations, this evidence provides useful information regarding the heterogeneity of the cross-sectional relationships across countries.

Lastly, we estimated both full sample and piecewise regressions for the four asset classes previously described for the pooled European sample and the entire sample of banks in each country. If the data generating process for each country sample of banks is sufficiently homogenous and the number of observations for each sample is small, a pooled model allows to obtain more precise coefficient estimates. In our pooled regressions, we controlled for the macroeconomic environment and for indicators of differences in the institutional and regulatory environment.

\subsection{U.S. Bank Holding Companies}

Table 2 reports regression results for the sample of U.S. BHCs relative to the 1988-1998 period in five panels, each reporting the results of regressions (3)-(7). To save space we do not report tables with coefficients estimates for the sub-periods. Instead, we report in figure 1 predicted values of the estimated cross-sectional relationships for the period 1988-1998, as well as for for two sub-periods 1988-1993 and 1994-1998.

\section{Charter value and size}

As shown in the first panel of table 2, the size coefficient of the charter value regression is negative and significant. When we consider asset classes, relevant size-related differences emerge. For the smallest banks in Q1, the size coefficients is positive and significant. Banks in Q2 exhibit a negative and significant size coefficient, whereas for banks in Q3 the size coefficient is not significantly different from zero. For the largest banks in the Q4 class we find a negative 
and significant coefficient associated with size. When the estimates for the asset classes are combined, we find that the relationship between charter value and size is approximately concave in size, as shown in the first graph of figure 1. It increases for small banks, starts to decrease at some size in Q2, and decreases significantly for larger banks. As shown in the first row of graphs in figure 1, the relationship between size and charter value in both sub-periods is similar to that found for the full period.

For the full sample, size growth is positevely and significantly related to charter value. However, such positive relationship does not hold uniformly for banks in each asset class. In fact, it is present for banks in Q1 and Q3, but absent for banks in Q2. Noticeably, size growth has no effect on the charter value of the largest banks in Q4. If we assume a permanent percentage increase in size, such increase results in a decrease in charter value, measured by the size coefficient, always larger, in absolute value, than the positive effect due to size growth, as measured by the size growth coefficient. For example, in the full sample a permanent $10 \%$ growth in size results in a net change in charter value of $-0.054 \%$. A standard test shows that such a decrease is significantly different from zero. Thus, size growth does not alter the negative relationship between asset size and charter value.

\section{Insolvency risk and size}

As shown in the second panel of table 2, the size coefficient of the insolvency risk regressions is negative and significant in the full sample. Thus, for the full sample insolvency risk increases

in size. Again, differences among asset classes emerge. The size coefficient is negative and significant only for banks with sizes larger than the median, those in Q3 and Q4. Size growth is positively associated with insolvency risk, but its coefficient is much smaller than the size coefficient. As shown in the second row of graphs in figure 1, the size-insolvency risk relationship is qualitatively unaltered in each sub-period.

The relationship between size and the components of insolvency risk is consistent with a differential behavior of small banks. As can be seen from the third panel of table 1, returns on assets decrease in size for the full sample and for the largest banks in asset class Q4. However, the asset class regressions and the third row of graphs in figure 1 show that for small banks, increases in size result in higher returns on assets, higher market capital-to-asset ratios and lower volatility, up to a threshold size included in the Q2 class. Increases in size beyond this threshold result in exactly the opposite movements, namely decreases in returns on assets, market capitalto-asset ratio and volatility. Specifically, the fourth panel of table 1 shows that the market 
capital-to-asset ratio decreases in size for the full sample and all asset classes except Q1 and Q2. As per the last panel of table 1, for the full sample banks' return volatility appears unrelated to size and slightly decreases in size growth. However, when the results of piecewise regressions are combined, the fifth row of graphs in figure 1 shows that volatility decreases in size for small banks, does not vary with size for medium-sized banks, and increases in size for larger banks. Figure 1 also shows that all these results are qualitatively similar for the two sub-periods.

Comparing the estimates of equation (5) and (7), the relationship between size and the ratio of bank returns over volatility is positive for small to medium sized banks, and negative for large banks. Thus, increases in size from small sizes result in higher return-lower risk points on a hypothetical risk-return frontier, whereas increases in size from medium to large sizes result in a movement in the opposite direction, i.e. towards a lower return/higher risk point on such frontier. Comparing the estimates of equation (6) and (7), the ratio of the market capital-to asset ratio over volatility, which can be viewed as a proxy of a risk-adjusted capital ratio, increases in size for small banks and decreases in size for medium to large banks.

The results for U.S. BHCs can be summarized as follows:

1. Charter value is approximately concave in size.

2. Insolvency risk is increasing in size.

3. The return to assets and the market capital-to-asset ratio are approximately concave in size.

4. Banks' return volatility is approximately convex in size.

Interesting facts emerge from a comparison of our results with the existing evidence. BR considered data up to the year 1990, hence their data set overlaps with ours only for three years out of eleven. Moreover, their sample includes only BHCs with sizes in our Q3 and Q4 asset classes, so that a comparison of our results with theirs is limited to these asset classes. Our results 1 and 3 are consistent with their evidence.

Differences with their results appear for results 2. BR found no significant relationship between insolvency risk and size, whereas we find a negative and significant one. Thus, insolvency risk appears to have increased for the larger BHCs in the U.S. during the 90s. Our results are 
also consistent with the evidence reported by Hughes et al. (1999), who consider market data for a sample of 190 BHCs for the year 1994 only.

Result 4 also differs from BR results. BR found a negative relationship between size and banks' return volatility, which they interpreted as evidence of diversification advantages associated with size. Demsetz and Strahan $(1995,1997)$ found similar results for BHCs' data corresponding to our Q3 and Q4 classes, and extending up to 1994. They provided evidence regarding the existence of diversification benefits in the form of a negative relationship between size and bank returns' volatility. However, they also found that these benefits were partially offset by banks' higher risk taking through riskier asset composition choices. We find exactly the opposite in more recent U.S. data that include a range of sizes sensibly larger than that considered by these authors, and in which there is no survivirship bias. Our results suggest that diversification benefits, if they existed, have been more than offset by higher risk-taking of medium-to-large banks in recent years.

Finally, the evidence for small U.S. bank holding companies is consistent with the existence of (economically relevant) economies of scale at small sizes, since our result qualitatively matches similar findings of the large literature focusing on the operational efficieny of banks, as well as with evidence of improvements in post-merger performance for small banks found in Boyd and Graham (1998).

\subsection{Japanese Banks}

Regressions results and fitted values of regressions (3)-(7) for Japanese banks are reported in table 3 and figure 2 respectively.

\section{Charter value and size}

As shown in the first panel of table 3 , the coefficient of size in the charter value regressions is negative for the full sample, albeit marginally significant. When we look at the asset classes, a negative and significant relationship between asset size and charter value is found for the largest banks in Q4. Once the estimates for the asset classes are considered jointly, the relationship between charter value and size turns out to be approximately flat for small and medium banks, and negative for large banks. As can be seen from the first row of graphs in figure 2, the overall negative relationship between size and charter value is not different across subperiods. Interestingly, size growth does not have any significant impact on charter value for the full sample and most asset classes. 


\section{Insolvency risk and size}

As shown in the second panel of table 3, the size coefficient of the insolvency risk regressions is negative and significant in the full sample, as well for all asset classes but Q3. As shown in the second row of graphs in figure 2, insolvency risk increases in size for the full sample and for both sub-periods. Thus, the relationship between size and insolvency risk is positive. In addition, the negative relationship between size growth and insolvency risk is much smaller, in absolute value, than the positive one between insolvency risk and size.

Turning to the risk components, returns on assets decrease in size for small banks, increase in size for small-to-medium banks, and decrease in size for large banks. As shown in the third panel of table 3 and the third row of graphs of figure 2, the market capital-to-asset ratio increases in size and size growth does not affect this ratio. As shown in the fifth panel of table 3 and the last row of graphs in figure 2, banks' return volatility is increasing in size and slightly decreases in size growth. Thus, the implied relationship between size and the ratio of bank returns over volatility is negative for all banks. That is, an increase in size moves banks towards a lower return-higher risk point on a hypothetical risk-return frontier. Furthermore, the difference between the coefficients of the market capital-to-asset ratio equation and the volatility equation indicates a negative, albeit small, relationship between a proxy of risk-adjusted capital ratio and size.

The results for Japanese banks can be summarized as follows:

1. Charter value does not vary with size for small and medium size banks, and decreases in size for large banks.

2. Insolvency risk is increasing in size.

3. The risk adjusted capital-asset ratio increases in size.

4. Returns' volatility is increasing in bank size.

The cross-sectional relationships between charter value, insolvency risk and size found for Japanese banks are very similar to those found for U.S. BHCs. ${ }^{4}$ This finding may appear somewhat surprising in light of the differences in the macroeconomic and institutional environments

\footnotetext{
${ }^{4}$ Recall that the minimum size of a Japanese bank in the sample falls close to the upper limit of asset class Q2 for the U.S.
} 
in which these banks operate. As it will be apparent in the sequel, however, the similarities among banks of different countries in the dimensions of interest are more pervasive than initially expected.

\subsection{European banks}

Table 4 reports the regression results for the six European countries in which the number of banks in the sample exceed twenty.

As shown in the first panel of table 4, the charter value regressions exhibit a negative and significant size coefficient for Danish, German and Spanish banks. For the other three countries, the relevant coefficient is not significantly different from zero. Size growth is positively related with charter value for Italian and Spanish banks, but is negatively related with charter value for German banks.

Remarkably, the results of the insolvency risk regressions are qualitatively identical in all countries. The size coefficients are negative and significant size coefficient in all regressions. Size growth is negatively related to size only for Italian, Spanish and Swiss banks. However, for banks in these countries the reduction of insolvency risk due to size growth does not offset the positive relationship between size and insolvency risk.

When we look at the risk components, the banks in the six European countries exhibit, again, very similar relationships. Returns on assets and market capital-to-asset ratios decrease with size in all six countries, and the relevant coefficients are significantly different from zero. Volatility increases with size in all countries, although the size coefficients are statistically significant only for German, Italian and Swiss banks. Hence, in all six countries considered larger banks are placed on a lower return/higher risk point on a hypothetical risk-return frontier, and they exhibit lower risk-adjusted capital asset ratios.

Finally, we estimated regressions (3)-(7) for the two subperiods, and found that for all banks except Swiss banks, where relationships appear to change somewhat across subperiods, the subperiod results are very similar.

The results for the six European samples considered can be summarized as follows:

1. Charter value is negatively related to size for banks in some countries, and no country exhibit a positive relationship.

2. Insolvency risk increases in size. 
3. Returns on assets and the market capital-to-asset ratio are decreasing in size, and the volatility of banks' returns is non decreasing in size.

A remarkable degree of homogeneity among banks in the six European countries emerges with respect to the relationship between size, insolvency risk and its components. Some homogeneity is also found in terms of the charter value-size relationship, since no country exhibits a positive and significant relationship. Also, notice that the relationships between size, charter value and insolvency risk found for banks in the six European countries are very similar to those found for U.S. and Japanese banks of comparable size ranges. Such degree of homogeneity suggests that pooled regressions, where differences in the macroeconomic and the institutional environments are controlled for, might provide more precise estimates of the cross-sectional relationships of interest.

\subsection{Pooled Samples}

We focus on the pooled sample of the European banks, and the pooled sample of all banks, and augment regressions (3)-(7) with country-specific intercepts associated with a set of macroeconomic indicators, and a set of "structural" variables capturing cross-country differences in the institutional and regulatory environment, that we term environmental.

The macroeconomic environment in each country is captured by eight indicators measured by averages for the 1988-1998 period: GDP growth, inflation, short and long term interest rates, and proxies of their relevant volatilities, computed as averages of annualized quarterly standard deviations.

We chose four environmental variables to proxy for structural characteristics of the economic environment in each country. The first environmental variable is the 1996 ratio of stock market capitalization over GDP (SMCGDP). SMCGDP proxies for the importance of financial markets in the economy, and has been used in the literature focusing on explanations of the finance-growth nexus. The second environmental variable is the index of regulatory restrictions on permissible activities (REGREST) constructed by Barth, Caprio and Levine (1999). REGREST indexes the stringency of restrictions that are imposed on banks in carrying out security, insurance, real estate activities, and the degree to which banks are allowed to control non-financial firms. Each of these four components is classified with an index increasing in the restrictiveness of regulations, ranging from 1 to 4, and REGREST is a simple average of each component. ${ }^{5}$ The third environmental variable considered is the proxy of deposit insurance cov-

\footnotetext{
${ }^{5}$ Barth, Caprio and Levine suggest to use each of the components separately, given their finding of low cor-
} 
erage constructed by Garcia (1999), given by the ratio of 1999 deposit coverage to per capita GDP (DEPINSC). DEPINSC can be viewed as a proxy of the size of the explicit safety net, since measures the committed liability of an explicit deposit insurance system. A larger explicit safety net may be associated with higher safety net subsidies as well as with stricter bank regulatory standards. A timing problem is present for three European countries, Greece, Portugal and Sweden, where deposit insurance was introduced in 1995, 1992 and 1996 respectively. We estimated regressions with both null values, and values proportional to the number of year over which deposit insurance was in place during the sample period for these countries, and found no qualitative change in the results. The fourth environmental variable is the 1997 fraction of state owned bank asset (STATEOWN) reported by Barth, Caprio and Levine (1999). STATEOWN indexes possible direct distortions, as well as indirect distortions on private agents' behavior induced by state banks' behavior. The importance of banks' state ownership on countries' long term growth has been recently documented by La Porta et al. (2000).

Table 5 reports the values of the variables (panel A) and their correlations (panel B). Despite the relatively high correlations among some of them, these variables turn out to have a degree of independent variation sufficiently high to pin down their individual impact on charter value and insolvency risk. An indication of the explanatory power of macroeconomic indicators and environmental variables is given in table 6. It reports coefficients of determination for all regressions with macroeconomic variables only, with environmental variables only, with both macroeconomic and environmental variables, and with country dummies, for both the pooled European sample and the entire pooled sample. It turns out that both macroeconomic and environmental variables capture significant portions of cross-country variations in charter value, risk and its components. Indeed, their joint explanatory power is very close to that associated with country dummies.

Since the single country analyses previously carried out involve about $86 \%$ of banks in our sample, and no significant differences in results were found across subperiods, we report results of estimates of regressions (3)-(7) for the entire sample period only.

\subsubsection{European banks pool}

Table 7 reports the regression results for the full sample and four asset classes. To save space, regressions coefficients of the macroeconomic indicators are not reported.

relations among restrictions on permissible activities in a sample 66 countries, which includes many developing countries. However, we chose to use the average of the restrictions' indicators, since for our set of developed countries the correlation among components is very high (ranging from 0.67 to 0.83 ). 
The charter value regressions exhibit a negative and significant size coefficient for the full sample. When we look at asset classes, we find that the size coefficients are not significantly different from zero with the exception of class Q4, where the coefficient is positive and marginally significant. However, inspection of the regressions' predicted values reveals that the positive slope for large bank does not alter the overall negative relationship between charter value and size, but simply indicates a positive charter value-size relationship within large banks. The size growth coefficient is positive and significant for the full sample and all asset classes except Q4, where this coefficient is statistically not different from zero. Thus, the size-charter value relationship for European banks is negative, consistently with the results found for the six European countries previously analyzed.

The insolvency risk regressions exhibit a negative size coefficient for the full sample. The size coefficient for each asset class is not significantly different from zero except Q4. For the largest banks in Q4, the size coefficient is positive and significant. However, inspection of the plot of the regression's predicted values shows that the result of class Q4 does not change the overall positive relationship between size and insolvency risk captured by the full sample regression, but simply reveals a negative insolvency risk-size relationship within large banks. Overall, insolvency risk is increasing in size. In addition, the results of the regressions with the risk components are qualitatively identical to those obtained previously. For the full sample and most asset classes, the return on assets and the market capital-to-asset ratio decrease in size, and volatility increases in size.

The European pool results can be summarized as follows:

- Charter value is decreasing in size.

- Insolvency risk is increasing in size.

- Returns on assets and the market capital-to-asset ratio decreases in size, and banks' return volatility increases in size.

\subsubsection{The impact of environmental variables}

Table 8 reports the results for the pooled regressions. The scatter plots of insolvency risk and size, and returns and size, reveal that the U.S. data exhibit a shape very similar to that exhibited by banks in other countries, but their levels are remarkably detached from, and higher 
than those of the other countries. These differences in levels are only partially reduced once macroeconomic and environmental factors are controlled for. For these reasons, regressions (4) and (5) were augmented with a U.S. country dummy.

Given our previous results, it is not surprising to find a negative relationship between charter value and size, and a positive one between insolvency risk and size. Likewise, the cross-sectional relationships between the risk components and size are similar to those found previously.

The coefficient associated with the proxy of the size of financial markets, SMCGDP, is positive and significant in the charter value regressions and the insolvency risk regressions. Note that SMCGDP positively impacts on returns on assets and the market capital-to-asset ratio, and has no significant effect on volatility for the full sample. Thus, banks operating in countries with larger private financial markets exhibit higher charter values and lower insolvency risk than banks operating in countries with relatively smaller financial markets. The positive impact of financial markets's size on banks' charter value and insolvency risk suggests the existence of a positive externality of financial markets on bank intermediation. An interpretation of this result is that developed capital markets provide intermediaries enhanced sources of income and better diversification opportunities, as well as a stronger market discipline. The latter compels intermediaries to translate these enhanced income and diversification opportunities in higher risk-adjusted performance and lower insolvency risk.

The coefficient associated with the proxy of regulatory restrictions, REGREST, is not significantly different from zero in the full sample regression, albeit it is positive for small banks in Q2 and negative for large banks in Q4, indicating effects of regulatory restrictions that differ according to banks' size. Remarkably, insolvency risk significantly increases with the stringency of regulatory restrictions, and particularly for larger banks in Q3 and Q4. As shown in the second panel of table 7, this result is even stronger for European banks, where REGREST enters negatively and significantly in the insolvency risk regressions for the full sample as well as for all asset classes. In addition, regulatory restrictions negatively affect all risk components, since a higher level of regulatory restrictions negatively impacts on bank returns and on the market capital-to-asset ratio, and has a positive impact on banks' return volatility. Thus, banks operating in countries with stricter restrictions on banks' permissible activities appear to take on more risk than banks operating in an environment in which investment in such activities is permitted. The finding of a positive effect of lower regulatory restrictions on banks' insolvency risk is novel, and is consistent with the existence of diversification opportunities for scope diversification that are actually exploited under lax constraints on permissible banks' activities. In addition, such 
result is also consistent with the comparatively higher operational efficiency of universal banks vs. specialized banks found by Saunders and Wilson (1994) and Allen and Rai (1996) for a sample of international banks, and by Vander Vennet (2000) for a sample of European banks.

The coefficient associated with the proxy of the size of the safety net, DEPINSC, is not significantly different from zero in the full sample regression, but is positive and significant for the largest banks in Q4. This variable might capture a component of the safety net subsidy embedded in larger banks' charter values associated with TBTDA effects. Interestingly, insolvency risk significantly decreases with the size of safety net coverage, and the effect is the strongest for medium and large banks. Moreover, lower insolvency risk stems from a reduction in bank return volatility, since DEPINSC is negatively related to volatility, particularly for large banks. In sum, large banks operating in countries with a larger explicit safety net appear to enjoy a subsidy which pushes up their charter value. However, medium and large banks operating in countries with larger explicit safety nets exhibit lower insolvency risk then their peers operating in countries with smaller explicit safety nets. An interpretation of this result is that countries with a more extensive explicit safety net might also be those in which bank regulation and size-related differential regulation are the most stringent. However, a detailed assessment of this interpretation would require a measure of total size of the safety net (which should include explicit as well as implicit guarantees), as well as some measure of the differential "stringency" of bank regulation across countries, and is beyond the scope of this study. Thus, we view this interpretation as purely conjectural, and by no means excluding other explanations.

Lastly, we turn to the bank state ownership variable, STATEOWN. We find that banks operating in countries with a higher level of banks' state ownership exhibit lower charter values and higher insolvency risk. All the components of insolvency risk are negatively affected by state ownership, since returns on assets and market capital-to-asset ratios are lower, and volatility is higher, the higher is the level of bank state ownership. Notice that our sample includes a small fraction of banks with partial or total state ownership. Thus, the lower charter values and the higher insolvency risk due to bank state ownership partially reflects a negative externality imposed on private banks by state banks' subsidized competition, which may induce private banks to take on higher risk and to have lower charter values. Overall, our evidence reveals direct and indirect inefficiencies associated with bank state ownership, in addition to the negative effects of bank state ownership on growth and development uncovered by La Porta et al. (2000). 


\section{Discussion}

Our investigation has unveiled very similar cross-sectional relationships between bank size, charter value and insolvency risk across countries. Similar relationships are found for banks that operate in countries that share similar degrees of development, but are rather diverse in their financial structure as well as in their regulatory and institutional environment. Indeed, the homogeneity of results across countries in the dimensions of interest makes the assessment of the broad implications of theory previously described fairly robust.

The first prediction of theory is not supported by the data, since insolvency risk increases in size and charter value decreases in size, contrary to what prediction 1 states. Interestingly, the evidence of a negative size-insolvency risk relationship is exactly the opposite of what predicted by the model of Buchinsky and Yosha (1997), which is obtained in absence of deposit insurance.

Prediction 1 could be reconciled with the evidence under the assumption that market power is decreasing in size. In terms of the arguments of equations (1) and (2), a negative marketpower size relationship amounts to assuming that $M_{p}^{1}(A)$ and $M_{p}^{2}(A)$ are decreasing functions of size. If monopoly rents were sufficiently high for small banks, then the component of charter value due to monopoly rents would be high, and a negative charter value-size relationship could ensue. Similarly, a positive insolvency risk-size relationship could be generated by charter values boosted by monopoly rents. In terms of the theory asserting the disciplinary role of charter value, higher charter values would give incentives for small banks to take on less risk than larger banks.

Yet, this market power explanation does not appear supported by the data. As observed by $\mathrm{BR}$, if smaller banks enjoy monopoly rents larger than those of large banks, then increased competition due to deregulation would expose smaller banks to a comparatively larger reduction of such rents. Thus, an implication of the market power explanation is that we should observe a negative relationship between charter value and size in a period where regulation is in place, and a flatter one between size and charter value after deregulation.

The monopoly power explanation does not appear supported by the U.S. evidence. Deregulation was well under way during most of our sample period. As documented by BR, a positive size-charter value relationship was holding in the 70's, but a negative one was holding in the 80 's, i.e. during the deregulation period, contrary to an implication of the market power explanation. In addition, the increasing (decreasing) portions of the relationship between size and charter value (insolvency risk) that we found for small U.S. banks appears inconsistent with the assumption of an inverse market power-size relationship, unless such assumption is applicable 
only to banks in an intermediate size range. By a similar argument, the monopoly power explanation does not seem supported by both the Japanese and the European evidence. Albeit the second sub-period in Japan can be considered one in which deregulation was fully under way, the cross sectional relationships between size, charter value and risk are virtually unchanged among sub-periods. The evidence of the six European countries considered individually does not support the market power explanation either. In fact, for none of the six countries a negative relationship between size and charter value found in the first subperiod turns flat in the second period, which is a period during which deregulation has been essentially completed in all countries considered. Furthermore, a recent study by De Bandt and Davis (2000) on 1992-1996 data for a relatively large sample of French, German and Italian banks finds that measures of market power of large and small banks do not appear to differ significantly.

The difficulty in reconciling prediction 1 with the evidence indicates the value added of theoretical research focusing on modeling imperfect competition in banking, as well as focusing on enriched models of the banking firm by allowing firms' heterogeneity and general equilibrium considerations. More specifically, the benchmark result of Buchinsky and Yosha (1997) model, which counterfactually predicts a negative relationship between size and insolvency risk in the absence of deposit insurance, points out the importance of the incentive structure of the safety net, and suggests that an extension of that model might be a high value added endeavor.

It is also apparent that the second prediction of theory is not supported by the data. since we find no evidence of (economically relevant) economies of scale for medium-to-large bank sizes in all our samples. In addition, we do not find any evidence of a negative relationship between size and bank return volatility found in previous U.S. studies. On the contrary, such relationship is positive for U.S. banks, as well as for Japanese and European banks. We note that this evidence is not at variance with some implications suggested by Hellwig's and Winton's models, which allow a positive relationship between size, diversification and insolvency risk under certain assumptions. This suggests that further theoretical research along the lines of Hellwig's and Winton's papers appears among the most promising research avenues.

Finally, our evidence has implications regarding the potential effects of bank consolidation for banks' insolvency risk. Our results are consistent with a large literature that has failed to detect average efficiency benefits from the consolidation process involving large banks (see e.g. Berger et al. (1999)) The finding of a positive relationship between insolvency risk and size is a robust feature of many diverse banking systems, and does not appear to be offset even by permanent size growth. Hence, absent future structural changes in the fundamentals of technologies and 
incentive structures of banking markets in developed countries, bank consolidation is likely to result in an average increase in banks' insolvency risk. 


\section{References}

[1] Acharya, V.V., 2000, "Is The International Convergence of Capital Adequacy Regulation Desirable?", mimeo, April.

[2] Allen, F and Gale, D., 1999, "Comparing Financial Systems", The MIT Press.

[3] Allen, L and Rai, A., 1996, "Operational Efficiency in Banking: An International Comparison", Journal of Banking and Finance, May, 655-672.

[4] Aghion, P., Bolton, P. and Fries, S. 1999, "Optimal Design of Bank Bailouts: The Case of Transition Economies", Journal of Institutional and Theoretical Economics, March: 51-70.

[5] Barth, J.R., Caprio Jr., G. and Levine, R., 1999, "Banking Systems Around the Globe: Do Regulation and Ownership Affect Performance and Stability?", mimeo, November.

[6] Berger, A., Demsetz, R. and Strahan, P., 1999," The Consolidation of the Financial Services Industry: Causes, Consequences, and Implications for the Future", Journal of Banking and Finance, 23, 135-194.

[7] Boyd, J.H., Chang, C. and Smith, B. D. 2000, "Deposit Insurance: A Reconsideration", mimeo, March.

[8] Boyd, J.H. and Graham, S., 1998, "Consolidation in U.S. Banking: Implications for Efficiency and Risk", in Amihud, Y. and Miller, G. Eds., "Bank Mergers and Acquisitions", Kluwer.

[9] Boyd, J. and Prescott, E., 1986, "Financial Intermediary Coalitions", Journal of Economic Theory, 38, 211-232.

[10] Boyd, J.H and Rankle, D., 1993, "Size and Performance of Banking Firms", Journal of Monetary Economics, 31, 47-67.

[11] Buchinsky, M. and Yosha, O., 1997, "Endogenous Propability of Failure for a Financial Intermediary: A Dynamic Model", mimeo, August.

[12] Demsetz, R. and Strahan, P., 1995, "Historical Patterns and Recent Changes in the Relationship between Bank Holding Company Size and Risk", FRBNY Economic Policy Review, July: $13-26$. 
[13] Demsetz, R. and Strahan, P. 1997, "Diversification, Size, and Risk at Bank Holding Companies", Journal of Money, Credit and Banking, vol. 29, No.3, August: 300-313.

[14] Demsetz, R., Saidenberg, M. 1999, "Looking Beyond the CEO: Executive Compensation at Banks", Working Paper, January.

[15] Demsetz, R., Saidenberg, M. and Strahan, P. 1996, "Banks with Something to Lose: The Disciplinary Role of Franchise Value", FRBNY Economic Policy Review, October: 1-14.

[16] Diamond, D., 1984, "Financial Intermediation and Delegated Monitoring", Review of Economic Studies, 51, 393-414.

[17] Freixas, X, Rochet, J C, 1997, ”Microeconomics of Banking”, The MIT Press.

[18] Gopp, R and Vesala, J., 2000 "Deposit Insurance and Moral Hazard: Does the Counterfactual Matter?", mimeo, March.

[19] Hellmann, T., Murdock, K. and Stiglitz, J, 2000, "Liberalization, Moral Hazard and Prudential Regulation: Are Capital Requirements Enough?", American Economic Review, June.

[20] Hellwig, M, 1998, "Allowing for Risk Choices in Diamond's Financial Intermediation as Delegated Monitoring", Working Paper 98-04, SFB 504, University of Mannheim.

[21] Hughes, J, Lang W., Mester, L. and Moon C-G., 1999, "The Dollars and Sense of Bank Consolidation", Journal of Banking and Finance, 23: 291-324.

[22] Garcia, G, 1999, "Deposit Insurance: A Survey of Actual and Best Practices", IMF Working Paper 99/54, April.

[23] Kane, E.J. 2000, "Incentives for Banking Megamergers: What Motives Might Central-Bank Economists Infer from Event-Study Evidence?", Journal of Money, Credit and Banking, Vol.32,no.3, 673-701.

[24] Kareken, J. and Wallace, N., 1978, "Deposit Insurance and Bank Regulation: A Partial Equilibrium Exposition", Journal of Business, Vol.32, 51, 413-438.

[25] Keeley, Michael 1990, "Deposit Insurance, Risk and Market Power in Banking", American Economic Review, December, 1183-1200. 
[26] Krasa, S. and Villamil, A, 1992, "A Theory of Optimal Bank Size", Oxford Economic Papers, 44: 725-749.

[27] La Porta, R., Lopez-de-Silanes, F. and Shleifer, A., 2000, "Government Ownership of Banks", NBER Working Paper \# 7620, March.

[28] Lindenberg, E. and Ross, S., 1981, "Tobin's q Ratio and Industrial Organization", Journal of Business, vol. 54, 1, 1-32.

[29] Mailath, G. and Mester, L., 1994, "A Positive Analysis of Bank Closure", Journal of Financial Intermediation, 3: 272-299.

[30] Marcus, A., 1984, "Deregulation and Bank Financial Policy", Journal of Banking and Finance, 8: 557-565.

[31] Marshall, D. and Prescott, E., 2000, "Bank Capital Regulation With and Without StateContingent Penalties", mimeo, April.

[32] Matutes, C, and Vives, X., 2000, "Imperfect Competition, Risk Taking and Regulation in Banking", European Economic Review, 44, 1-34.

[33] Merton, R., 1977, "An Analytic Derivation of the Cost of Deposit Insurance and loan guarantees: An Application of Modern Option Pricing Theory" Journal of Banking and Finance, 1: 3-11.

[34] Roy, A. D., 1952, "Safety First and the Holding of Assets", Econometrica, 20, issue 3, 431-449.

[35] Saunders, A. and Walter, I, 1994, "Universal Banking in the United States", Oxford University Press, Oxford.

[36] Sleet, C. and Smith B.D., 2000, "Deposit Insurance and Lender of Last Resort Functions", Working Paper, September.

[37] Vander Vennet, R. 2000, "Are Financial Conglomerates and Universal Banks Efficient?", in Artis, Weber and Hennessy eds., The Euro, A Challenge and Opportunity for Financial Markets, Routledge International Studies in Money and Banking, n.10.

[38] Williamson, S., 1986, "Costly Monitoring, Financial Intermediation and Credit Rationing", Journal of Monetary Economics, 18, 159-179. 
[39] Winton, A, 1999, "Don’t Put All Your Eggs in One Basket? Diversification and Specialization in Lending", Working paper 9903, Finance Department, University of Minnesota. 
Table 1

Total Average Asset in US\$ million

1988-1998

\begin{tabular}{|l|c|c|c|c|c|c|c|}
\hline Country & \# of banks & Mean & Min & 25 perc & Median & 75 perc & Max \\
\hline AUSTRIA & 11 & 18212 & 609 & 3427 & 6218 & 22292 & 72775 \\
BELGIUM & 5 & 42674 & 2092 & 4199 & 8690 & 87457 & 110933 \\
DENMARK & 35 & 4829 & 69 & 121 & 339 & 1241 & 65699 \\
FINLAND & 6 & 16051 & 508 & 3016 & 10961 & 29625 & 37662 \\
FRANCE & 21 & 75193 & 832 & 3046 & 11430 & 121850 & 290879 \\
GERMANY & 27 & 62584 & 76 & 6831 & 19805 & 53207 & 392626 \\
GREECE & 11 & 11410 & 465 & 1038 & 5606 & 11331 & 44137 \\
IRELAND & 4 & 19724 & 2396 & 6405 & 19903 & 33222 & 36695 \\
ITALY & 41 & 23399 & 273 & 3319 & 7376 & 25962 & 147838 \\
LUXEMBURG & 5 & 21737 & 14652 & 17897 & 23523 & 23879 & 28734 \\
NETHERLAND & 8 & 41470 & 86 & 394 & 1796 & 10274 & 302130 \\
NORWAY & 15 & 5749 & 239 & 889 & 1768 & 4398 & 28478 \\
PORTUGAL & 12 & 8128 & 392 & 1114 & 4437 & 14674 & 28662 \\
SPAIN & 23 & 25112 & 809 & 2707 & 7724 & 32027 & 106796 \\
SWEDEN & 6 & 38966 & 1939 & 6053 & 43121 & 70596 & 72165 \\
SWITZERLAND & 29 & 25944 & 270 & 1325 & 3923 & 6392 & 237415 \\
U.K. & 12 & 90220 & 113 & 7502 & 52757 & 140306 & 311014 \\
\hline \hline EUROPE & 271 & 30931 & 69 & 1229 & 6078 & 24678 & 392626 \\
\hline AUSTRALIA & 9 & 38892 & 2106 & 4374 & 15807 & 76391 & 97003 \\
CANADA & 9 & 66535 & 823 & 19279 & 77447 & 103150 & 132426 \\
JAPAN & 118 & 60742 & 2472 & 12118 & 18560 & 37859 & 512534 \\
U.S. & 419 & 7168 & 45 & 365 & 902 & 3052 & 239364 \\
\hline POOL & 826 & 23610 & 45 & 608 & 2708 & 15784 & 512534 \\
\hline \hline
\end{tabular}


Table 2

U.S. Banks

$\log (\mathrm{Q})$

\begin{tabular}{|c|c|c|c|c|c|}
\hline & \multicolumn{5}{|c|}{ 1988-1998 } \\
\hline Sample & Full & Q1 & Q2 & Q3 & Q4 \\
\hline const. & $0.05^{* *}$ & $-0.07^{* *}$ & $0.27^{* *}$ & $\begin{array}{l}-0.03 \\
\end{array}$ & $0.14^{* *}$ \\
\hline t-stat & 4.45 & -2.03 & 2.25 & -0.29 & 3.87 \\
\hline $\log (\mathrm{A})$ & $-0.0066^{* *}$ & $0.0178^{* *}$ & $-0.0392^{* *}$ & 0.0034 & $-0.0162 * *$ \\
\hline t-stat & -4.30 & 2.47 & -2.05 & 0.25 & -4.36 \\
\hline$G(A)$ & $0.0012^{* *}$ & $0.0011^{* *}$ & -0.0002 & $0.0017^{* *}$ & 0.0016 \\
\hline t-stat & 3.93 & 2.73 & -0.36 & 4.10 & 1.43 \\
\hline Adj. R2 & 0.08 & 0.08 & 0.02 & 0.09 & 0.11 \\
\hline \multicolumn{6}{|c|}{$\log (\mathbf{Z})$} \\
\hline const. & $3.59^{* *}$ & $3.05^{* *}$ & $2.54^{* *}$ & $5.19^{* *}$ & $4.22^{* *}$ \\
\hline t-stat & 23.72 & 5.77 & 2.06 & 3.19 & 7.44 \\
\hline $\log (A)$ & $-0.1829 * *$ & -0.0544 & -0.0233 & $-0.3859^{*}$ & $-0.2979 * *$ \\
\hline t-stat & -8.44 & -0.54 & -0.13 & -1.76 & -5.15 \\
\hline$G(A)$ & $0.0173^{* *}$ & 0.0030 & $0.0157^{* *}$ & 0.0108 & $0.0554^{* *}$ \\
\hline t-stat & 4.27 & 0.53 & 2.49 & 1.62 & 4.41 \\
\hline Adj. R2 & 0.21 & -0.01 & 0.06 & 0.06 & 0.30 \\
\hline \multicolumn{6}{|c|}{$\log (\mathbf{R})$} \\
\hline const. & $3.77^{* *}$ & $1.90 *$ & 2.80 & $5.37^{* *}$ & $4.90^{* *}$ \\
\hline t-stat & 16.79 & 1.72 & 1.56 & 2.22 & 6.59 \\
\hline $\log (A)$ & $-0.1844^{* *}$ & 0.1914 & -0.0196 & -0.3926 & $-0.3551 * *$ \\
\hline t-stat & -6.52 & 0.94 & -0.07 & -1.21 & -4.83 \\
\hline $\mathbf{G}(\mathrm{A})$ & $0.0188^{* *}$ & 0.0037 & $0.0181 *$ & 0.0132 & $0.0582^{* *}$ \\
\hline t-stat & 3.46 & 0.40 & 1.90 & 1.27 & 4.62 \\
\hline Adj. R2 & 0.13 & -0.01 & 0.03 & 0.03 & 0.27 \\
\hline \multicolumn{6}{|c|}{$\log (\mathrm{E} / \mathrm{A})$} \\
\hline const. & $-1.82^{* *}$ & $-3.03^{* *}$ & $-1.94^{* *}$ & -1.15 & $-1.76^{* *}$ \\
\hline t-stat & -20.15 & -10.01 & -2.90 & -1.64 & -6.85 \\
\hline $\log (A)$ & $-0.0644^{* *}$ & $0.1765^{* *}$ & -0.0266 & $-0.1615^{*}$ & $-0.0871^{* *}$ \\
\hline t-stat & -5.69 & 2.99 & -0.25 & -1.73 & -3.19 \\
\hline $\mathrm{G}(\mathrm{A})$ & $0.0125^{* *}$ & $0.0075^{* *}$ & 0.0058 & $0.0135^{* *}$ & $0.0253^{* *}$ \\
\hline t-stat & 6.22 & 2.07 & 1.49 & 3.85 & 4.44 \\
\hline Adj. R2 & 0.19 & 0.08 & 0.01 & 0.25 & 0.25 \\
\hline \multicolumn{6}{|c|}{$\log ($ Sigma $)$} \\
\hline const. & $-0.20^{* *}$ & $1.14^{*}$ & -0.29 & 0.04 & $-0.53^{* *}$ \\
\hline t-stat & -2.06 & 1.74 & -0.34 & 0.05 & -1.96 \\
\hline $\log (\mathrm{A})$ & 0.0103 & $-0.2457^{* *}$ & 0.0303 & -0.0282 & $0.0611^{* *}$ \\
\hline t-stat & 0.88 & -2.08 & 0.24 & -0.25 & 2.30 \\
\hline $\mathbf{G}(\mathrm{A})$ & $-0.0038^{*}$ & -0.0008 & 0.0001 & -0.0021 & $-0.0151^{* *}$ \\
\hline t-stat & -1.62 & -0.17 & 0.02 & -0.54 & -2.69 \\
\hline Adj. R2 & 0.01 & 0.05 & 0.00 & -0.01 & 0.11 \\
\hline
\end{tabular}

Notes: Standard errors are computed using White's correction for heteoschedasticity. $* *(*)$ indicates significance at the 5\% (10\%) confidence level. 
Table 3

Japanese Banks

$\log (\mathrm{Q})$

\begin{tabular}{|c|c|c|c|c|c|}
\hline & \multicolumn{5}{|c|}{ 1988-1998 } \\
\hline Sample & Full & Q1 & Q2 & Q3 & Q4 \\
\hline const. & $0.15^{*}$ & 0.03 & 0.21 & 0.06 & $0.51^{*}$ \\
\hline t-stat & 1.77 & 1.00 & 1.22 & 0.76 & 1.90 \\
\hline $\log (\mathrm{A})$ & $-0.0150^{*}$ & -0.0026 & -0.0200 & -0.0038 & $-0.0459^{*}$ \\
\hline t-stat & -1.63 & -0.71 & -1.11 & -0.45 & -1.87 \\
\hline $\mathrm{G}(\mathrm{A})$ & 0.0018 & 0.0007 & $-0.0009 * *$ & $-0.0019^{*}$ & 0.0071 \\
\hline t-stat & 0.90 & 0.75 & -1.91 & -1.77 & 1.25 \\
\hline Adj. R2 & 0.06 & -0.04 & 0.04 & -0.01 & 0.03 \\
\hline \multicolumn{6}{|c|}{$\log (\mathrm{Z})$} \\
\hline const. & -0.52 & $10.51^{* *}$ & $9.61^{* *}$ & -0.58 & 0.72 \\
\hline t-stat & -0.83 & 3.44 & 2.01 & -0.17 & 1.15 \\
\hline $\log (\mathrm{A})$ & $-0.1315^{* *}$ & $-1.4262^{* *}$ & $-1.1711^{* *}$ & -0.1307 & $-0.2283^{* *}$ \\
\hline t-stat & -2.37 & -4.13 & -2.34 & -0.40 & -4.28 \\
\hline $\mathrm{G}(\mathrm{A})$ & $0.0515^{* *}$ & $0.1992^{* *}$ & -0.0039 & 0.0652 & $0.0614^{* *}$ \\
\hline t-stat & 1.97 & 3.98 & -0.43 & 1.58 & 2.36 \\
\hline Adj. R2 & 0.13 & 0.43 & 0.11 & 0.01 & 0.40 \\
\hline \multicolumn{6}{|c|}{$\log (\mathbf{R})$} \\
\hline const. & $4.49^{* *}$ & $24.13^{* *}$ & 16.80 & 7.18 & $7.28^{* *}$ \\
\hline t-stat & 3.68 & 4.09 & 1.63 & -1.28 & 5.86 \\
\hline $\log (A)$ & $-0.6326^{* *}$ & $-2.925^{* *}$ & $-1.9305^{*}$ & 0.5180 & $-0.8437^{* *}$ \\
\hline t-stat & -5.73 & -4.34 & -1.81 & 0.94 & -7.94 \\
\hline $\mathrm{G}(\mathrm{A})$ & 0.0442 & $0.2622^{* *}$ & 0.0248 & 0.0524 & 0.0254 \\
\hline t-stat & 1.00 & 1.94 & 1.01 & 0.77 & 0.62 \\
\hline Adj. R2 & 0.30 & 0.38 & 0.05 & -0.03 & 0.68 \\
\hline \multicolumn{6}{|c|}{$\log (\mathbf{E} / \mathbf{A})$} \\
\hline const. & $-4.31^{* *}$ & $-3.69^{* *}$ & 0.72 & $-2.76^{* *}$ & $-3.14^{* *}$ \\
\hline t-stat & -24.45 & -5.15 & 0.27 & -2.08 & -6.78 \\
\hline $\log (\mathrm{A})$ & $0.1551^{* *}$ & 0.0729 & -0.3585 & 0.0058 & 0.0549 \\
\hline t-stat & 9.49 & 0.90 & -1.31 & 0.04 & 1.44 \\
\hline $\mathbf{G}(\mathrm{A})$ & 0.0037 & 0.0127 & $-0.0139^{* *}$ & 0.0059 & 0.0217 \\
\hline t-stat & 0.37 & 0.75 & -1.92 & 0.24 & 1.08 \\
\hline Adj. R2 & 0.42 & -0.02 & 0.06 & -0.07 & 0.07 \\
\hline \multicolumn{6}{|c|}{$\log ($ Sigma $)$} \\
\hline const. & $-2.08^{* *}$ & $-10.59^{* *}$ & -5.72 & -2.49 & $-1.77^{* *}$ \\
\hline t-stat & -3.77 & -3.86 & -1.48 & -1.02 & -3.65 \\
\hline $\log (\mathrm{A})$ & $0.1936^{* *}$ & $1.1879^{* *}$ & 0.5650 & 0.2432 & $0.1593^{* *}$ \\
\hline t-stat & 3.96 & 3.85 & 1.41 & 0.98 & 3.75 \\
\hline $\mathrm{G}(\mathrm{A})$ & $-0.0561^{* *}$ & -0.1960 & -0.0121 & $-0.0669^{*}$ & $-0.0498^{* *}$ \\
\hline t-stat & -2.27 & -4.25 & -1.06 & -1.70 & -3.03 \\
\hline Adj. R2 & 0.29 & 0.48 & 0.02 & 0.07 & 0.39 \\
\hline
\end{tabular}

Notes: Standard errors are computed using White's correction for heteoschedasticity. $* *(*)$ indicates significance at the 5\% (10\%) confidence level. 
Table 4

European Banks

\begin{tabular}{|l|ccc|ccc|}
\hline Dependent variable & \multicolumn{3}{|c}{$\log (\mathbf{Q})$} & \multicolumn{3}{c|}{$\log (\mathbf{Z})$} \\
\hline Country & $\log (\mathbf{A})$ & $\mathbf{G}(\mathbf{A})$ & $\mathrm{R} 2$ & $\mathbf{L o g}(\mathbf{A})$ & $\mathbf{G}(\mathbf{A})$ & $\mathrm{R} 2$ \\
\hline DENMARK & $-0.0065^{* *}$ & 0.0002 & 0.14 & $-0.1652^{* *}$ & 0.0239 & 0.26 \\
t-stat & -3.06 & 0.47 & & -3.95 & 1.41 & \\
\hline FRANCE & 0.0009 & 0.0020 & -0.05 & $-0.2334^{* *}$ & -0.0089 & 0.24 \\
t-stat & 0.13 & 1.61 & & -4.78 & -0.90 & \\
\hline GERMANY & $-0.0289^{* *}$ & $-0.0028^{* *}$ & 0.29 & $-0.5515^{* *}$ & -0.0161 & 0.39 \\
t-stat & -2.86 & -2.79 & & -3.00 & -1.50 & \\
\hline ITALY & -0.0101 & $0.0014^{* *}$ & 0.16 & $-0.3055^{* *}$ & $0.0069^{* *}$ & 0.47 \\
t-stat & -0.97 & 6.16 & & -7.01 & 4.79 & \\
\hline SPAIN & $-0.0191^{* *}$ & 0.0020 & 0.36 & $-0.2018^{* *}$ & $0.0393^{* *}$ & 0.13 \\
t-stat & -3.78 & 1.06 & & -2.93 & 2.96 & \\
\hline SWITZERLAND & 0.0050 & $0.0026^{*}$ & 0.05 & $-0.1223^{*}$ & $0.0239^{* *}$ & 0.27 \\
t-stat & 0.36 & 1.87 & & -1.83 & 8.89 & \\
\hline
\end{tabular}

\begin{tabular}{|l|ccc|ccc|}
\hline Dependent variable & \multicolumn{3}{|c}{$\log (\mathbf{E} / \mathbf{A})$} & \multicolumn{3}{c|}{$\log ($ Sigma $)$} \\
\hline Country & Log(A) & G(A) & R2 & Log(A) & G(A) & R2 \\
\hline DENMARK & $-0.1520^{* *}$ & 0.0123 & 0.58 & 0.0345 & -0.0125 & 0.01 \\
t-stat & -6.73 & 1.54 & & 1.50 & -1.32 & \\
\hline FRANCE & $-0.1803^{* *}$ & -0.0039 & 0.19 & 0.0419 & -0.0045 & 0.05 \\
t-stat & -3.92 & -0.55 & & 1.54 & -0.76 & \\
\hline GERMANY & $-0.2840^{* *}$ & $-0.0172^{* *}$ & 0.55 & $0.3326^{* *}$ & $0.0181^{* *}$ & 0.36 \\
t-stat & -3.89 & -4.21 & & 4.35 & 2.35 & \\
\hline ITALY & $-0.2642^{* *}$ & $0.0088^{* *}$ & 0.62 & $0.0614^{* *}$ & $0.0016^{*}$ & 0.04 \\
t-stat & -6.29 & 11.05 & & 2.64 & 1.65 & \\
\hline SPAIN & $-0.1324^{* *}$ & 0.0079 & 0.27 & 0.0456 & 0.0064 & -0.05 \\
t-stat & -4.12 & 0.63 & & 0.83 & 0.33 & \\
\hline SWITZERLAND & $-0.1308^{* *}$ & $0.0186^{* *}$ & 0.13 & $0.0642^{* *}$ & $0.0054^{* *}$ & 0.06 \\
t-stat & -2.35 & 4.89 & & 2.18 & 2.85 & \\
\hline
\end{tabular}

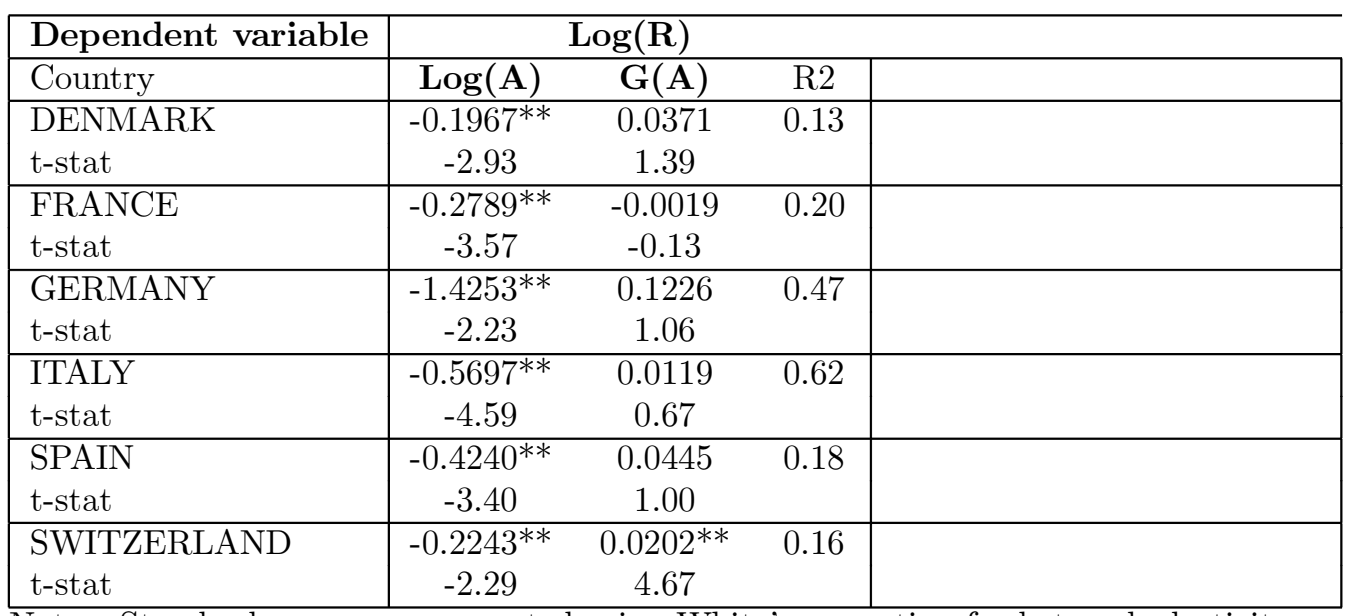

Notes: Standard errors are computed using White's correction for heteoschedasticity.

** (*) indicates significance at the 5\% (10\%) confidence level. 
Table 5

\begin{tabular}{l|c|c|c|c|}
\hline \multicolumn{5}{c}{ Panel A: Environmental Variables } \\
\hline Country & SMCGDP & REGREST & DEPINSC & STATEOWN \\
\hline AUSTRIA & 0.97 & 1.25 & 0.90 & 0.04 \\
BELGIUM & 0.82 & 2.50 & 0.70 & 0.00 \\
DENMARK & 4.54 & 1.75 & 0.70 & 0.00 \\
FINLAND & 6.52 & 1.75 & 1.20 & 0.41 \\
FRANCE & 4.97 & 2.00 & 2.60 & 0.14 \\
GERMANY & 13.00 & 1.75 & 0.80 & 0.43 \\
GREECE & 0.00 & 2.25 & 0.00 & 0.63 \\
IRELAND & 43.33 & 1.75 & 0.80 & 0.00 \\
ITALY & 0.09 & 2.25 & 6.10 & 0.25 \\
LUXEMBURG & 0.94 & 1.50 & 0.40 & 0.00 \\
NETHERLAND & 40.76 & 1.50 & 0.90 & 0.00 \\
NORWAY & 3.09 & 2.00 & 7.90 & 0.38 \\
PORTUGAL & 0.00 & 2.00 & 0.00 & 0.17 \\
SPAIN & 0.17 & 1.75 & 1.20 & 0.02 \\
SWEDEN & 8.19 & 3.00 & 0.00 & 0.00 \\
SWITZERLAND & 87.75 & 1.50 & 0.50 & 0.15 \\
U.K. & 144.91 & 1.25 & 1.40 & 0.00 \\
\hline AUSTRALIA & 32.25 & 2.00 & 0.00 & 0.00 \\
CANADA & 32.59 & 2.25 & 2.10 & 0.00 \\
JAPAN & 0.37 & 3.25 & 3.05 & 0.00 \\
U.S. & 58.22 & 3.00 & 3.20 & 0.00 \\
\hline \hline
\end{tabular}

Panel B: Correlations of Environmental Variables

\begin{tabular}{l|c|c|c|c|}
\hline & SMCGDP & REGREST & DEPINSC & \\
\hline REGREST & 0.22 & & & \\
DEPINSC & 0.03 & 0.46 & & \\
STATEOWN & -0.41 & -0.52 & -0.02 & \\
\hline
\end{tabular}


Table 6

Adjusted R2 of regressions (1)-(5)

on macroeconomic variables, environmental variables bank size and bank growth

\begin{tabular}{|c|c|c|c|c|}
\hline $\begin{array}{l}\text { dependent } \\
\text { variable }\end{array}$ & $\begin{array}{c}\text { macroeconomic } \\
\text { variables }\end{array}$ & $\begin{array}{c}\text { environmental } \\
\text { variables }\end{array}$ & $\begin{array}{c}\text { macroeconomic+ } \\
\text { environmental } \\
\text { variables }\end{array}$ & $\begin{array}{c}\text { country } \\
\text { dummies }\end{array}$ \\
\hline \multicolumn{5}{|c|}{ European pool } \\
\hline $\log (\mathrm{Q})$ & 0.21 & 0.09 & 0.25 & 0.28 \\
\hline $\log (\mathrm{Z})$ & 0.36 & 0.34 & 0.69 & 0.72 \\
\hline $\log (\mathrm{R})$ & 0.32 & 0.32 & 0.64 & 0.68 \\
\hline $\log (\mathrm{E} / \mathrm{A})$ & 0.30 & 0.28 & 0.36 & 0.36 \\
\hline Log(Sigma) & 0.36 & 0.39 & 0.55 & 0.63 \\
\hline \multicolumn{5}{|c|}{ POOL } \\
\hline $\log (\mathrm{Q})$ & 0.26 & 0.28 & 0.37 & 0.39 \\
\hline $\log (Z)$ & 0.61 & 0.72 & 0.85 & 0.89 \\
\hline $\log (\mathrm{R})$ & 0.59 & 0.64 & 0.76 & 0.81 \\
\hline $\log (\mathrm{E} / \mathrm{A})$ & 0.36 & 0.35 & 0.39 & 0.40 \\
\hline $\log ($ Sigma $)$ & 0.10 & 0.25 & 0.37 & 0.44 \\
\hline
\end{tabular}


Table 7

European Banks Pool

\begin{tabular}{|c|c|c|c|c|c|}
\hline \multicolumn{6}{|c|}{ Panel 1} \\
\hline Dependent variable & \multicolumn{5}{|c|}{$\log (\mathbf{Q})$} \\
\hline Sample & Full & Q1 & Q2 & Q3 & Q4 \\
\hline SMGDP & $0.0007^{* *}$ & 0.0003 & $0.0020^{* *}$ & 0.0004 & -0.0005 \\
\hline t-stat & 2.39 & 0.27 & 2.06 & 0.83 & -1.52 \\
\hline REGREST & -0.0077 & 0.0125 & -0.0664 & -0.0346 & $-0.1221^{* *}$ \\
\hline t-stat & -0.20 & 0.04 & -0.67 & -0.69 & -3.09 \\
\hline DEPINSC & -0.0091 & -0.0210 & 0.0107 & -0.0153 & $0.0257^{* *}$ \\
\hline t-stat & -0.95 & -0.68 & 0.53 & -0.98 & 2.33 \\
\hline STATEOWN & -0.0993 & 0.1650 & -0.1832 & 0.0207 & $-0.3911^{* *}$ \\
\hline t-stat & -0.79 & 0.40 & -1.07 & 0.10 & -3.45 \\
\hline $\log (A)$ & $-0.0089^{* *}$ & 0.0040 & -0.0425 & 0.0482 & $0.0260^{*}$ \\
\hline t-stat & -2.62 & 0.44 & -1.22 & 1.43 & 1.71 \\
\hline $\mathbf{G}(\mathbf{A})$ & $0.0013^{* *}$ & $0.0026^{*}$ & $0.0009^{*}$ & $0.0014^{* *}$ & 0.0001 \\
\hline t-stat & 5.10 & 1.69 & 1.62 & 5.91 & 0.10 \\
\hline Adj. R2 & 0.25 & 0.33 & 0.22 & 0.27 & 0.37 \\
\hline \multicolumn{6}{|c|}{ Panel 2} \\
\hline Dependent variable & \multicolumn{5}{|c|}{$\log (Z)$} \\
\hline Sample & Full & Q1 & Q2 & Q3 & $\mathrm{Q} 4$ \\
\hline SMGDP & $0.0309^{* *}$ & $0.0256^{* *}$ & $0.0190^{* *}$ & $0.0190 * *$ & $0.0307^{* *}$ \\
\hline t-stat & 11.70 & 2.72 & 3.15 & 5.32 & 7.98 \\
\hline REGREST & $-2.3829 * *$ & $4.1548^{* *}$ & $-3.2653^{* *}$ & $-2.9167^{* *}$ & $-3.5115^{* *}$ \\
\hline t-stat & -6.70 & 1.97 & -3.47 & -5.53 & -8.20 \\
\hline DEPINSC & 0.0295 & 0.0449 & 0.3579 & 0.0877 & $0.4435^{* *}$ \\
\hline t-stat & 0.30 & 0.16 & 1.55 & 0.62 & 4.02 \\
\hline STATEOWN & -1.1527 & $-6.2179^{*}$ & $-6.0278^{* *}$ & -0.4360 & $-5.0780 * *$ \\
\hline t-stat & -0.88 & -1.74 & -2.34 & -0.29 & -4.11 \\
\hline $\log (A)$ & $-0.2337 * *$ & -0.1180 & $-0.2680^{*}$ & $-0.4460 *$ & $0.3540 * *$ \\
\hline t-stat & -5.45 & -0.96 & -1.52 & -1.81 & 2.71 \\
\hline $\mathbf{G}(\mathbf{A})$ & $0.0095^{* *}$ & $0.0279 * *$ & 0.0069 & $0.0066 * *$ & $0.0139 * *$ \\
\hline t-stat & 4.05 & 6.37 & 1.17 & 5.21 & 4.17 \\
\hline Adj. R2 & 0.69 & 0.70 & 0.66 & 0.59 & 0.90 \\
\hline \multicolumn{6}{|c|}{ 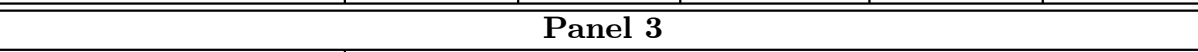 } \\
\hline Dependent variable & \multicolumn{5}{|c|}{$\log (\mathbf{R})$} \\
\hline Sample & Full & Q1 & Q2 & Q3 & $\mathrm{Q} 4$ \\
\hline SMGDP & $0.0338^{* *}$ & $0.0196^{*}$ & $0.0266^{* *}$ & $0.0265^{* *}$ & $0.0371^{* *}$ \\
\hline t-stat & 9.91 & 1.62 & 2.66 & 7.99 & 4.65 \\
\hline REGREST & $-2.3870 * *$ & 3.2198 & -2.5433 & $-2.9058^{* *}$ & $-3.4600^{* *}$ \\
\hline t-stat & -4.94 & 1.20 & -1.44 & -4.97 & -3.27 \\
\hline DEPINSC & $-0.2950^{*}$ & -0.3066 & $0.8017^{* *}$ & -0.1604 & 0.1049 \\
\hline t-stat & -1.73 & -0.79 & 3.68 & -0.85 & 0.25 \\
\hline STATEOWN & 2.5465 & -4.1025 & $-18.0093 * *$ & 3.7423 & -3.4935 \\
\hline t-stat & 1.02 & -0.90 & -3.10 & 1.42 & -0.63 \\
\hline $\log (A)$ & $-0.2892^{* *}$ & 0.0735 & -0.0218 & $-1.1404^{* *}$ & 0.3223 \\
\hline t-stat & -6.38 & 0.45 & -0.07 & -3.15 & 1.31 \\
\hline $\mathbf{G}(\mathrm{A})$ & $0.0160 * *$ & $0.0317^{* *}$ & $0.0219 * *$ & 0.0120 & $0.0136 * *$ \\
\hline t-stat & 3.47 & 3.57 & 2.32 & 1.16 & 2.21 \\
\hline Adj. R2 & 0.64 & 0.59 & 0.54 & 0.63 & 0.84 \\
\hline
\end{tabular}


Table 7 (cont.)

European Pool

\begin{tabular}{|c|c|c|c|c|c|}
\hline \multicolumn{6}{|c|}{ Panel 4} \\
\hline Dependent variable & \multicolumn{5}{|c|}{$\log (\mathrm{E} / \mathrm{A})$} \\
\hline Sample & Full & Q1 & Q2 & Q3 & Q4 \\
\hline SMGDP & $0.0066^{* *}$ & $-0.0116^{* *}$ & $0.0108^{* *}$ & $0.0031^{*}$ & $0.0062^{* *}$ \\
\hline t-stat & 3.82 & -2.09 & 2.50 & 1.68 & 2.46 \\
\hline REGREST & -0.1784 & -1.0250 & $0.9013^{* *}$ & 0.2000 & $-0.7249 * *$ \\
\hline t-stat & -0.88 & -1.09 & 2.48 & 0.95 & -2.55 \\
\hline DEPINSC & -0.0547 & $0.3202^{* *}$ & $-0.3315^{* *}$ & -0.0927 & 0.0880 \\
\hline t-stat & -1.07 & 2.66 & -4.46 & -1.25 & 1.17 \\
\hline STATEOWN & -0.0550 & $-1.9498^{*}$ & $3.5323^{* *}$ & 0.3415 & $-1.4577^{*}$ \\
\hline t-stat & -0.08 & -1.48 & 4.31 & 0.42 & -1.86 \\
\hline $\log (A)$ & $-0.1836^{* *}$ & $-0.1351^{* *}$ & $-0.3976^{* *}$ & $-0.3073^{*}$ & -0.0170 \\
\hline t-stat & -7.88 & -2.16 & -2.30 & -1.72 & -0.16 \\
\hline $\mathbf{G}(\mathbf{A})$ & $0.0084^{* *}$ & $0.0139 * *$ & $0.0061^{* *}$ & $0.0087^{* *}$ & 0.0047 \\
\hline t-stat & 6.77 & 3.47 & 2.72 & 9.89 & 1.15 \\
\hline Adj. R2 & 0.36 & 0.70 & 0.12 & 0.24 & 0.44 \\
\hline \multicolumn{6}{|c|}{ Panel 5 } \\
\hline Dependent variable & \multicolumn{5}{|c|}{ Log(Sigma) } \\
\hline Sample & Full & Q1 & Q2 & Q3 & $\mathrm{Q} 4$ \\
\hline SMGDP & 0.0015 & 0.0040 & $-0.0072^{* *}$ & 0.0015 & $0.0061^{*}$ \\
\hline t-stat & 0.92 & 1.16 & -2.34 & 0.64 & 1.98 \\
\hline REGREST & 0.1707 & -1.0601 & $-0.7231^{*}$ & $0.4734^{*}$ & $0.8542^{* *}$ \\
\hline t-stat & 0.98 & -0.90 & -1.85 & 1.76 & 3.67 \\
\hline DEPINSC & $-0.2651^{* *}$ & -0.0216 & -0.1041 & $-0.2143^{* *}$ & $-0.4924^{* *}$ \\
\hline t-stat & -4.64 & -0.31 & -1.15 & -2.38 & -7.47 \\
\hline STATEOWN & $5.4690 * *$ & 1.9785 & $4.4786^{* *}$ & $4.4654^{* *}$ & $8.7019 * *$ \\
\hline t-stat & 6.96 & 1.47 & 4.41 & 3.73 & 9.55 \\
\hline $\log (A)$ & $0.1009^{* *}$ & $-0.1292^{* *}$ & -0.0507 & $0.5086^{* *}$ & -0.0418 \\
\hline t-stat & 5.00 & -2.07 & -0.44 & 2.23 & -0.51 \\
\hline$G(A)$ & $0.0028^{*}$ & -0.0011 & $0.0054^{*}$ & $0.0018^{*}$ & 0.0004 \\
\hline t-stat & 1.94 & -0.30 & 2.16 & 1.70 & 0.14 \\
\hline Adj. R2 & 0.55 & 0.45 & 0.54 & 0.47 & 0.85 \\
\hline
\end{tabular}

Notes: Standard errors are computed using White's correction for heteoschedasticity. ** $(*)$ indicates significance at the $5 \%(10 \%)$ confidence level. 
Table 8

Pool

\begin{tabular}{|l|c|c|c|c|c|}
\hline \hline \multicolumn{7}{c}{ Panel 1 } \\
\hline Dependent variable & \multicolumn{7}{c}{ Log(Q) } \\
\hline Sample & Full & Q1 & Q2 & Q3 & Q4 \\
\hline SMGDP & $0.0005^{* *}$ & 0.0001 & 0.0010 & 0.0014 & -0.0002 \\
t-stat & 2.06 & 0.14 & 1.55 & 1.18 & -0.71 \\
REGREST & 0.0160 & 0.0002 & $0.1082^{*}$ & 0.1130 & $-0.0559^{*}$ \\
t-stat & 0.44 & 0.01 & 1.95 & 0.91 & -1.90 \\
DEPINSC & -0.0019 & 0.0000 & $-0.0291^{*}$ & -0.0253 & $0.0194^{* *}$ \\
t-stat & -0.28 & NA & -1.76 & -1.13 & 3.39 \\
STATEOWN & $-0.1913^{* *}$ & 0.0000 & 0.2572 & 0.0991 & $-0.4176^{* *}$ \\
t-stat & -2.59 & NA & 1.31 & 0.39 & -7.23 \\
\hline Log(A) & $-0.0077^{* *}$ & 0.0045 & 0.0039 & -0.0070 & -0.0119 \\
t-stat & -4.48 & 0.92 & 0.28 & -0.56 & -1.43 \\
G(A) & $0.0012^{* *}$ & $0.0017^{* *}$ & $0.0015^{* *}$ & $0.0013^{* *}$ & 0.0006 \\
t-stat & 5.92 & 2.99 & 2.55 & 4.46 & 1.20 \\
\hline Adj. R2 & 0.37 & 0.36 & 0.22 & 0.47 & 0.39 \\
\hline \hline
\end{tabular}

Panel 2

\begin{tabular}{|l|c|c|c|c|c|}
\hline \multicolumn{7}{|c|}{ Panel 2 } \\
\hline Dependent variable & \multicolumn{7}{|c|}{ Log(Z) } \\
\hline Sample & Full & Q1 & Q2 & Q3 & Q4 \\
\hline t-stat & $0.0302^{* *}$ & $0.0203^{* *}$ & $0.0172^{* *}$ & $0.0156^{* *}$ & $0.0367^{* *}$ \\
REGREST & 10.89 & 2.18 & 2.60 & 2.11 & 9.28 \\
t-stat & $-1.8783^{* *}$ & $0.8734^{*}$ & $-2.0976^{* *}$ & $-3.2209^{* *}$ & $-1.8633^{* *}$ \\
DEPINSC & -4.66 & 1.89 & -2.74 & -4.78 & -4.31 \\
t-stat & $0.2162^{* *}$ & 0.0000 & $0.2901^{*}$ & $0.3857^{* *}$ & $0.3010^{* *}$ \\
STATEOWN & 3.53 & NA & 1.89 & 3.18 & 3.30 \\
t-stat & $-3.9282^{* *}$ & 0.0000 & $-6.1904^{* *}$ & $-5.3262^{* *}$ & $-3.9488^{* *}$ \\
\hline Log(A) & -4.74 & NA & -2.45 & -3.86 & -5.24 \\
t-stat & $-0.1935^{* *}$ & -0.0513 & $-0.2680^{* *}$ & -0.0514 & $-0.1129^{* *}$ \\
G(A) & -9.16 & -0.77 & -2.05 & -0.37 & -2.35 \\
t-stat & $0.0110^{* *}$ & $0.0123^{* *}$ & $0.0169^{* *}$ & $0.0103^{* *}$ & $0.0130^{* *}$ \\
\hline Adj. R2 & 4.20 & 2.77 & 3.77 & 3.26 & 2.56 \\
\hline \hline \multicolumn{7}{|c|}{ Panel 3 } & 0.81 & 0.83 & 0.84 & 0.87 \\
\hline
\end{tabular}

\begin{tabular}{|l|c|c|c|c|c|}
\hline Dependent variable & \multicolumn{5}{|c|}{ Log(R) } \\
\hline Sample & Full & Q1 & Q2 & Q3 & Q4 \\
\hline SMGDP & $0.0330^{* *}$ & 0.0154 & 0.0130 & $0.0272^{* *}$ & $0.0414^{* *}$ \\
t-stat & 9.10 & 1.34 & 1.52 & 2.75 & 6.86 \\
REGREST & $-1.8995^{* *}$ & 0.5544 & $-2.4971^{* *}$ & $-3.2840^{* *}$ & $-2.0782^{* *}$ \\
t-stat & -3.01 & 0.97 & -2.24 & -3.51 & -2.94 \\
DEPINSC & 0.1403 & 0.0000 & 0.1952 & $0.3526^{*}$ & 0.2044 \\
t-stat & 1.15 & NA & 0.74 & 1.95 & 1.06 \\
STATEOWN & $-3.7905^{* *}$ & 0.0000 & $-7.5356^{* *}$ & $-3.9925^{* *}$ & $-5.6796^{* *}$ \\
t-stat & -2.06 & NA & -1.73 & -1.74 & -2.54 \\
\hline Log(A) & $-0.2428^{* *}$ & 0.1223 & -0.3034 & -0.2156 & $-0.3564^{* *}$ \\
t-stat & -9.67 & 1.09 & -1.56 & -1.13 & -4.49 \\
G(A) & $0.0168^{* *}$ & $0.0138^{* *}$ & $0.0206^{* *}$ & $0.0538^{* *}$ & $0.0186^{* *}$ \\
t-stat & 4.54 & 2.02 & 2.93 & 5.34 & 2.38 \\
\hline Adj. R2 & 0.79 & 0.65 & 0.72 & 0.75 & 0.83 \\
\hline \hline
\end{tabular}


Table 8 (cont.)

Pool

\begin{tabular}{|c|c|c|c|c|c|}
\hline \multicolumn{6}{|c|}{ Panel 4} \\
\hline Dependent variable & \multicolumn{5}{|c|}{$\log (\mathbf{E} / \mathbf{A})$} \\
\hline Sample & Full & Q1 & Q2 & Q3 & Q4 \\
\hline SMGDP & $0.0045^{* *}$ & $-0.0163^{* *}$ & $0.0060^{* *}$ & -0.0021 & $0.0060^{* *}$ \\
\hline t-stat & 3.08 & -4.46 & 2.24 & -0.59 & 3.40 \\
\hline REGREST & $-0.3128^{*}$ & $-0.7829^{* *}$ & 0.2076 & $-0.6559 *$ & $-0.4244^{*}$ \\
\hline t-stat & -1.69 & -5.25 & 0.87 & -1.70 & -1.63 \\
\hline DEPINSC & -0.0185 & 0.0000 & $-0.1791^{* *}$ & 0.0642 & 0.0457 \\
\hline t-stat & -0.62 & NA & -3.90 & 0.95 & 1.36 \\
\hline STATEOWN & -0.2636 & 0.0000 & $2.3039 * *$ & -0.9510 & $-0.7871^{* *}$ \\
\hline t-stat & -0.62 & NA & 3.26 & -1.28 & -2.51 \\
\hline $\log (A)$ & $-0.0916^{* *}$ & $0.0586^{*}$ & $-0.1283^{* *}$ & 0.0228 & 0.0368 \\
\hline t-stat & -7.68 & 1.61 & -1.88 & 0.32 & 1.23 \\
\hline $\mathbf{G}(\mathbf{A})$ & $0.0088^{* *}$ & $0.0091^{* *}$ & $0.0107 * *$ & $0.0092^{* *}$ & 0.0043 \\
\hline t-stat & 8.28 & 3.35 & 4.32 & 8.55 & 1.39 \\
\hline Adj. R2 & 0.39 & 0.41 & 0.35 & 0.37 & 0.40 \\
\hline \multicolumn{6}{|c|}{ Panel 5} \\
\hline Dependent variable & \multicolumn{5}{|c|}{ Log(Sigma) } \\
\hline Sample & Full & Q1 & $\mathrm{Q} 2$ & Q3 & $\mathrm{Q} 4$ \\
\hline SMGDP & 0.0018 & $0.0079^{* *}$ & 0.0020 & -0.0014 & 0.0018 \\
\hline t-stat & 1.17 & 3.30 & 0.57 & -0.30 & 0.87 \\
\hline REGREST & $0.4030 * *$ & $0.4628^{* *}$ & -0.0157 & 0.3599 & $0.5203^{*}$ \\
\hline t-stat & 2.31 & 3.89 & -0.04 & 1.27 & 1.70 \\
\hline DEPINSC & $-0.2188^{* *}$ & 0.0000 & -0.0911 & $-0.2249 * *$ & $-0.2616^{* *}$ \\
\hline t-stat & -5.97 & NA & -0.65 & -3.14 & -5.76 \\
\hline STATEOWN & $4.7666^{* *}$ & 0.0000 & 3.5169 & $4.4660 * *$ & $5.6256^{* *}$ \\
\hline t-stat & 8.78 & NA & 1.46 & 3.96 & 10.04 \\
\hline $\log (A)$ & $0.0636^{* *}$ & $-0.1661^{* *}$ & 0.0452 & $0.1667^{* *}$ & $0.0833^{* *}$ \\
\hline t-stat & 5.83 & -2.86 & 0.55 & 2.01 & 2.61 \\
\hline $\mathbf{G}(\mathrm{A})$ & 0.0007 & -0.0014 & -0.0015 & 0.0005 & -0.0041 \\
\hline t-stat & 0.70 & -0.45 & -0.59 & 0.35 & -1.26 \\
\hline Adj. R2 & 0.38 & 0.09 & 0.25 & 0.32 & 0.70 \\
\hline
\end{tabular}

Notes: Standard errors are computed using White's correction for heteoschedasticity. ** $(*)$ indicates significance at the $5 \%(10 \%)$ confidence level. 


\section{Figure 1: U.S. Bank Holding Companies}
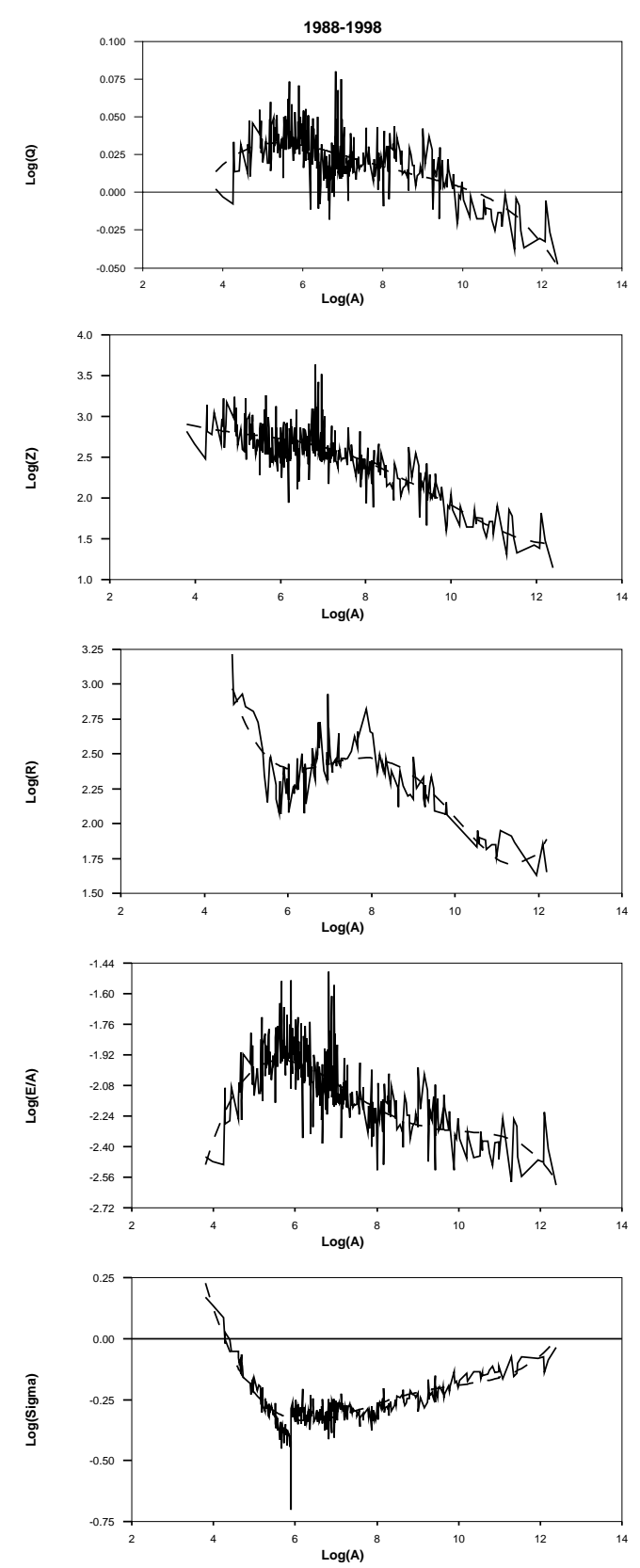
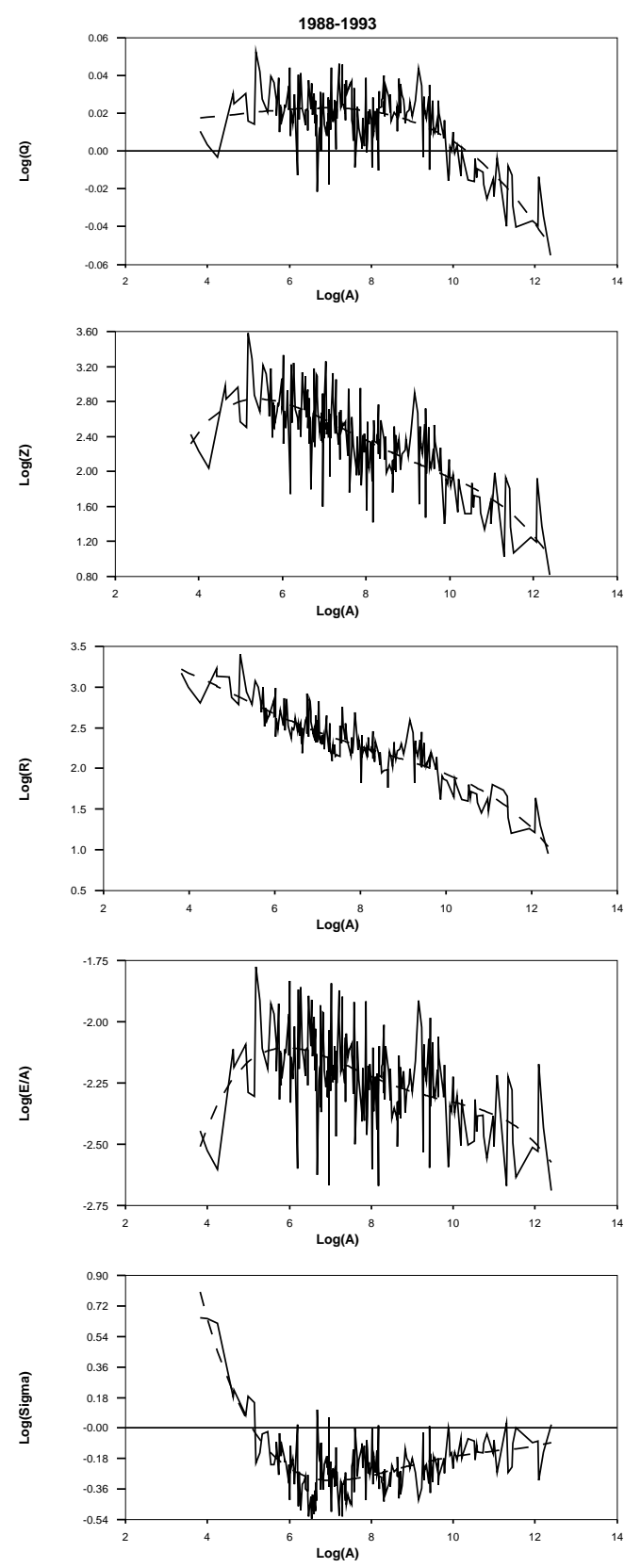

1994-1998
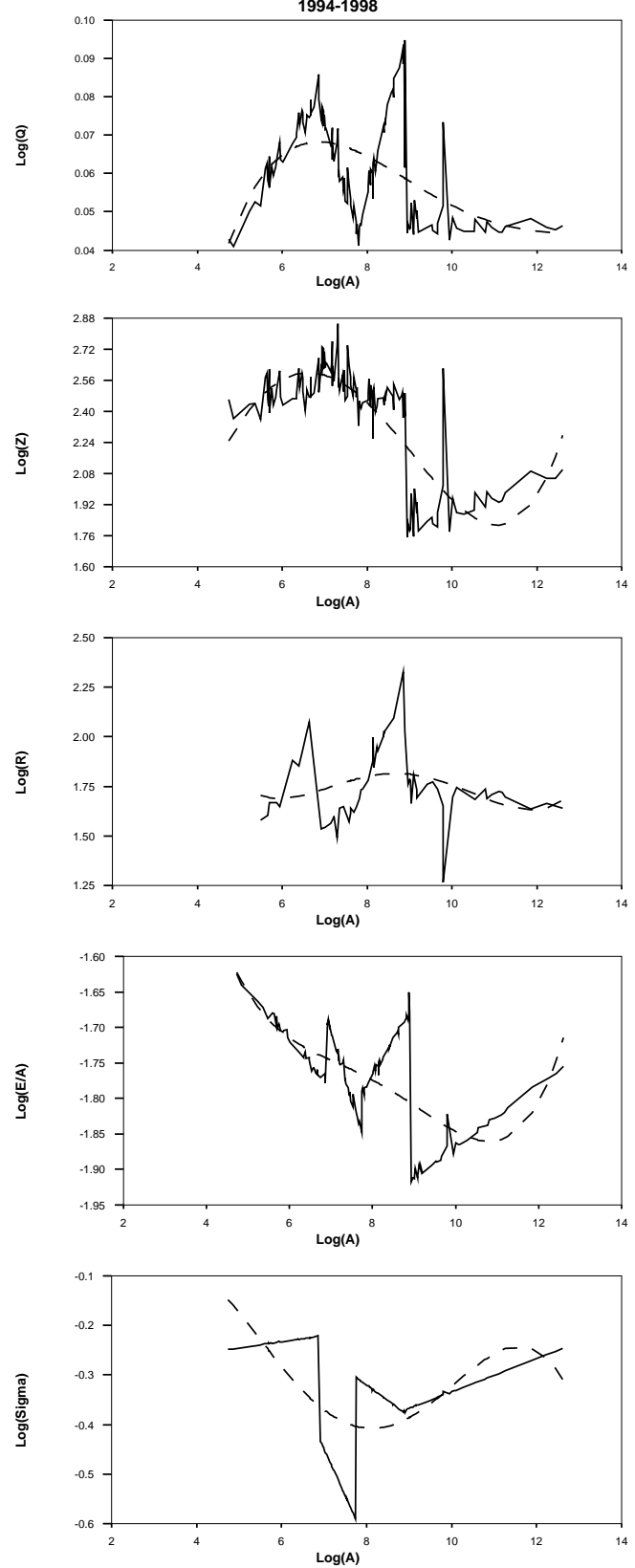
Figure 2: Japanese Banks
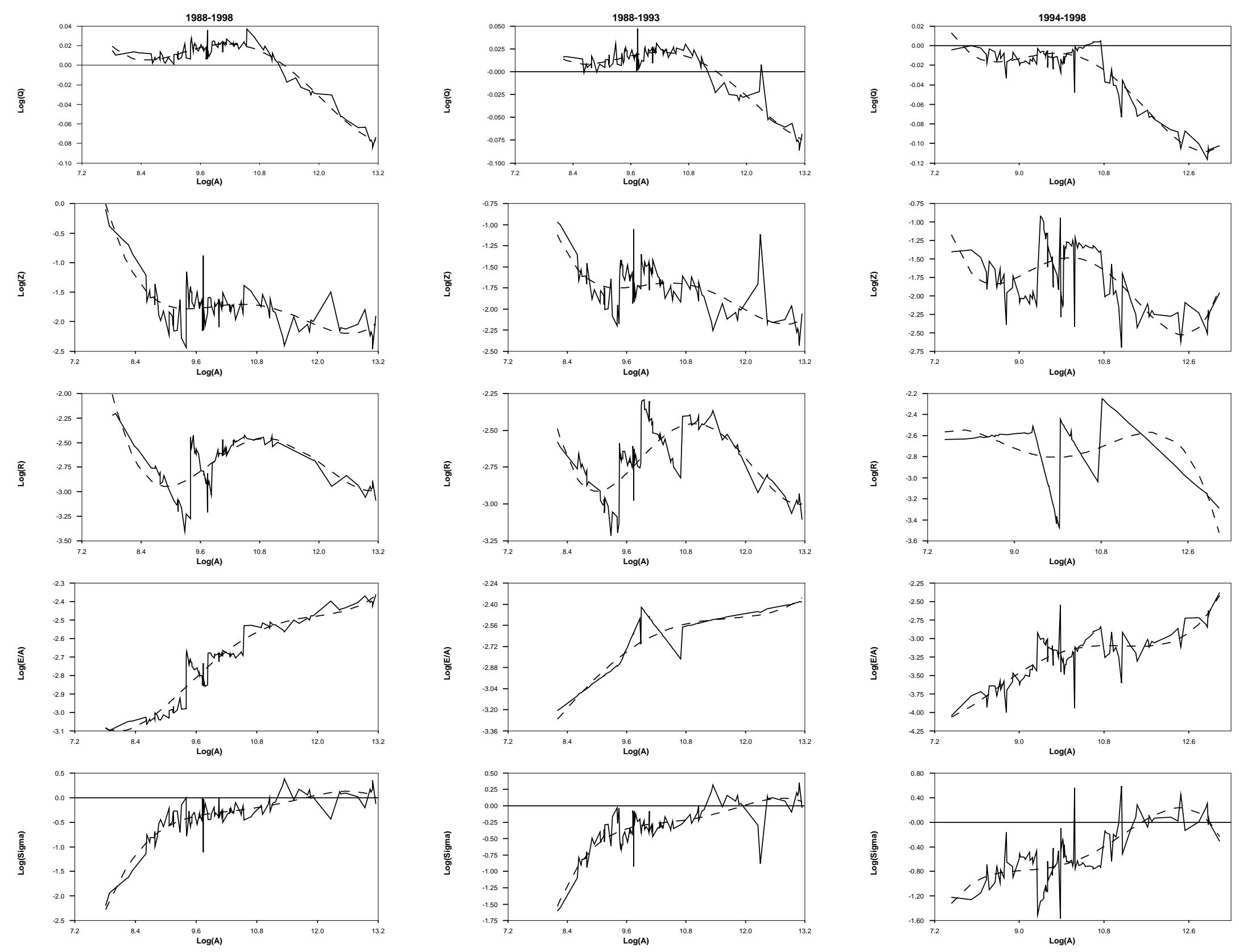